\title{
Osmanlı Batılılaşmasının Giresun-Piraziz'e Yansımaları: Tiralizade Konaklarının Cephe Tasarımı
}

\author{
Ahmet Ali BAYHAN* \\ Gülferi AKIN ERTEK** \\ Özgül YILDIRIM GÜNEŞ*** \\ $\ddot{O} z$
}

Osmanlı Devleti, XVIII. yüzyılda başta askeri alanda olmak üzere birçok alanı iyileştirmek maksadıyla batıyla olan bağlantısını kuvvetlendirmiş ve modernleşme yoluna gitmiştir. Batılılaşma çabalarıyla ve Avrupa'daki uygulamalara dayanarak devletin her mekanizmasını revize etmeye çalışmıştır. Bu çerçevede batılılaşma çabalarının sanatsal tezahürü de XVIII. yüzyıldan itibaren görülmeye başlamıştır. Mimaride, batılı üsluplar öncelikle başkent İstanbul'da bir müddet sonra da taşrada inşa edilen dini, sivil ve askeri yapı gruplarında etkisini göstermiştir.

XVIII. yüzyılda inşa edilen farklı yapı gruplarında öncelikle Avrupa ülkelerinde hâkim olan Rokoko ile Barok üslupların süsleme detaylarında ve cephe tasarımlarında etkileri görülmektedir. XIX. yüzyıl sonlarında ise Ampir, Neoklasisizm gibi batılı birçok üslup ve doğulu (Oryantalizm) birçok unsur ya tek başına ya da bir arada (Eklektik biçimde) çoğunlukla gayrimüslim ya da yabancı mimarlar aracıllğıyla mimaride yerlerini almıştır.

Geleneksel cephe tasarımlarında inşa edilen konaklar haricinde cepheleri batılı üsluplarla şekillendirilen konak örneklerine ise hemen her şehirde rastlamak mümkündür. Bu yapıların banileri şehrin ileri gelen varlıklı aileleridir. Dönemin yeniliklerini takip eden, inşa ettirdikleri yapıları prestij unsuru olarak da öne çıkarmak isteyen bu ailelerden biri Karadeniz Bölgesi'nde bulunan Tiralizadelerdir. XIX. yüzyılda ayanlık payesi verilen Tirelizadelerin bir taşra şehri olan Giresun'un Piraziz İlçesi'nde inşa ettirdiği konaklarda batılı üsluplara özgü düzenlemelerin yer aldığg açıkça görülebilmektedir. Bu bağlamda Tiralizade ailesine ait konaklarda, XX. yüzyıl itibari ile batılı etki ile cephe yüzeylerinde kendini gösteren süsleme ve tasarım ögelerinin incelenmesi çalışmamızın konusunu oluşturmaktadır. Karadeniz'deki sahil yerleşiminde varlıklı ailelere ait tespit edilen konaklar üzerine yapılan bu çalışmayla Geç Osmanlı dönemi mimarisine yeni örnekler kazandırılmış olacaktır.

Anahtar Kelimeler: Batılılaşma, Konak, Tirali, Cephe, Tasarım.

\section{Reflections of Ottoman Westernization on Giresun-Piraziz: Facade Design of Tiralizade Mansions}

\begin{abstract}
In the XVIIIth century, the Ottoman Empire strengthened its connection with the West in order to improve many fields, especially the military field, and went on the path of modernization. The Empire tried to revise every mechanism of the state based on Westernization efforts and practices in Europe. In this context, the artistic manifestation of Westernization efforts began to be seen from the XVIIIth century. In architecture, the western styles first manifested their influence on the religious, civil, and military building groups built in the capital, Istanbul, and after a while in the countryside.

In the different building groups constructed in the XVIIIth century, the effects of the Rococo and Baroque styles, which were dominant in European countries, are seen in the ornamental details and facade designs. At the end of the XIXth century, many western influences as Imperial, Neoclassicism, or many eastern (Orientalism) influences took their place in architecture either alone or together (in an Eclectic manner), mostly by non-Muslim or foreign architects.

Apart from the mansions built with traditional facade designs, it is possible to come across mansions whose facades are shaped with western styles in almost every city. The patrons of these structures are the prominent wealthy families of the city. One of these families, who followed the innovations of the period and wanted to highlight the buildings they had constructed as a factor of prestige, is the Tiralizades in the Black Sea Region. It can be clearly

\footnotetext{
* Prof. Dr., Ordu Üniversitesi Fen Edebiyat Fakültesi, Sanat Tarihi Bölümü, bayhanahmetali@hotmail.com, ORCID: 00000003-2496-6136.

** Arş. Gör., Fen Edebiyat Fakültesi, Sanat Tarihi Bölümü, gulferiakin@odu.edu.tr, ORCID: 0000-0002-8753-9206.

*** Arş. Gör., Fen Edebiyat Fakültesi, Sanat Tarihi Bölümü, ozgulyildirim@odu.edu.tr, ORCID: 0000-0002-9092-8990. (Makale Türü: Araștırma Makalesi)
} 
seen that the mansions built in the Piraziz district of Giresun by Tiralizades, who were deemed worthy of the rank of notables in the XIXth century, have arrangements specific to western styles. In this context, the subject of our study is the examination of the ornamentation and design elements that manifest themselves on the facade surfaces with the western influence as of the XXth century in the mansions built the Tiralizade Family. With this study on mansions belonging to wealthy families in the coastal settlement of the Black Sea, new examples will be brought on the late Ottoman period architecture.

Key words: Westernization, Mansion, Tirali, Facade, Design

Geliş/Received: 21.09 .2021

Kabul/Accepted: 30.12 .2021

- Bu çalışma, insanlardan veri ve örnek toplamayı gerektiren, anket, inceleme, alan çalışması ve deney içeren araştırmalar kapsamına girmediğinden etik kurul onay belgesi gerektirmemektedir

\section{Giriş}

XVIII. yüzyılda Lale Devri'yle başlayan Batılı etkiler kısa bir süre içerisinde Osmanlı mimarisinde karşılık bulmuştur. Batılı üsluplar, mimarideki etkilerini ilk olarak başkent İstanbul ve İzmir, Antalya gibi önemli liman şehirlerinde göstermiş, kısa zaman diliminde taşrada inşa edilen kamu ve sivil işlevli yapı gruplarında uygulanmaya başlanmışır. Başlangıçta Rokoko ve Barok ekseninde bezemede ve sonrasında cephe teşkilatında öne çıkan üsluplar, özellikle XVIII. yüzyılın ikinci yarısından itibaren Neoklasist bir anlayışa dönüşmüş, XIX. yüzyıl sonlarında ise batılı ve doğulu birçok üslubu içerisinde barındıran Eklektik tarz, mimari detay ve cephe tasarımında kendini göstermiştir. Batılılaşma dönemi Osmanlı mimarisinde yapı cephelerinde kullanılan geleneksel motiflerin yanında akant yaprakları, kıvrımlı kemerler, madalyonlar, belirgin korniş ve silmeler gibi bazı motifler belirginleşmiştir (Schulz, 1979: 10; Atasoy, 1985: 33-34; Andersan, 1890; Pevsner, 1977; Briggs, 1914; Blunt, 1988; Naeuman, 2013. Christian Norberg-Schulz, 1980: 7-10). XIX. yüzyılın başlarından itibaren Osmanlı mimarlığının içerisine dâhil olan XVIII. yüzyılda Napoli merkezli olarak ortaya çıkan Neoklasik üslubun mimarideki şekillenişi üç tür planlama esasına dayalı olarak gelişmiştir. Bunlar klasik blok, Andrea Palladio'nun villa tasarımlarına dayanan tür ve Yunan tapınakları biçimindeki tasarımlardır (Toman, 2010; Middleton ve Watkin, 1980; Akın, 2019: 31; Yiğitpaşa ve Akın Ertek, 2020: 219-258). III. Selim'in askeri alanda getirdiği yenilikler sonucunda, Avrupa mimarisinde devlet otoritesini temsil eden birçok örnekte uygulanan Neoklasisizm, Osmanlı mimarisinde de resmi mimari üslup olarak tercih edilerek askeri, idari ve kamu yapılarında uygulanmıştır. Fransa'da Neoklasisizm'in ikinci evresi olarak değerlendirilen Ampir üslup ise Napolyon Bonapart'ın ideal İmparatorluk anlayışına uygun olarak gelişmiştir. Üslup, Roma mirasını mimariye yansıtmak adına rozet, kargı, meşale gibi birtakım motiflerin Neoklasik binalara uygulanması şeklinde görülmektedir (Rouge, 2008; Englund, 2004; Honour, 1977; Hitchcock, 1958: 48-49; Fredlund, 2008: 108). Ampir üsluba ait bu motiflerin çağdaş dönemde Osmanlı'da inşa edilmiş Neoklasik yapılarda savaş ve müzik aletleri ile bayrak gibi motiflerle karşılık bulmuştur (Çelik, 1986: 114). XIX. yüzyılda bahsedilen bu üslupların haricinde Avrupa'da ortaya çıan Neogotik (Aldrich, 2005; Clark, 1983; Eastlake, 2012; Germann, 1972), Art Nouveau (Bony, 2012; Bouillon, 1985; Duncan, 1994) gibi üslup çeşitliliği Osmanlı mimarisinde, 
Oryantalist eğilim ve Mağrip üsluplarının eklenmesiyle gelişmiştir. Bu üsluplarda tasarlanan yapıların ise başta padişah olmak üzere, üst düzey yöneticiler, Levanten ve gayrimüslimler himayesinde yabanc1yerel gayrimüslim mimarlarca uygulandığı takip edilebilmektedir (Yiğitpaşa ve Uz, 2016: 22-43).

Bir liman şehri olan Giresun'un Piraziz ilçesinde XX. yüzyıl itibari ile yörenin önde gelen ailelerinden Tiralizadeler tarafından inşa ettirilen konakların cephelerinde batı mimarlığının etkisini taşıyan süsleme ve tasarım ögelerinin incelenmesi çalışmanın konusunu oluşturmaktadır. ${ }^{1}$ Bu bağlamda Osmanlı Devleti'nde ayanlık, ayan olarak Tiralizade ailesinin Giresun-Piraziz'deki rolü ve onların inşa ettirdiği 6 konak bani, mimar ve yapı özelinde değerlendirilmiştir. ${ }^{2}$

\section{Osmanlı Devleti'nde Ayanlar ve Tiralizade Ailesi}

XVII. yüzyıldan itibaren artan ve kötü sonuçlanan savaşların etkisiyle mali durumu kötüleşmiş olan Osmanlı Devleti’nin şehirlerdeki hâkimiyeti zayıflamıştır. Anadolu'daki karışıklıkların çoğalması, otorite zayıflı̆̆ı ve vergi toplama problemi (Özkaya, 2014: 119) XVII. yüzyıl sonundan XVIII. yüzyılın başlarına kadar ortaya çıkan ve XVIII. yüzyılın ilk yarısında kendi bölgelerini yöneten "Derebeyleri" şeklinde tanımlanan güçleri yaratmıştır (Sümer, 1992: 83). Bu güçler, Anadolu'nun çoğu taşrasında XIX. yüzyıla dek yaygınlaşmıştır (Özkaya, 2014: 17). XVIII. yüzyılın başında Osmanlı Devleti'nin kontrolünden çıkan bu güçler tanınmak zorunda kalmış, bazı kelimelerde ise kullanım değişikliğine gidilmiştir. Derebeyleri “Ayan” olarak tanımlanmış, bu kişilere "oğlu” kelimesi yerine "zade” ismi verilmeye başlanmıştır (Sümer, 1992: 103). Devletçe tanınmış ayan aileleri, kimi zaman hükümetin görevlileriyle iletişim halinde olup idari görevlerde yer almıştır. Devlet, ihtiyaç dâhilinde ayanlardan asker sağlamak için yardım istemiştir (Özkaya, 2014: 153; Yüksel, 2013: 33). Varlıklı olmalarının verdiği avantajla güç ve etkilerini sürdüren ayanlar (Yüksel, 2013: 33) bulundukları şehirlerin imar ve inşa faaliyetlerinde büyük rol oynamışlardır. ${ }^{3}$

XIX. yüzyılda farklı sancakların kaza ve nahiyesi olan Piraziz'in önde gelen ailelerinden Tiralizadeler ise XVIII. yüzyıldan itibaren Karadeniz'de çıkan ayaklanmalarda devlete yardım etmiş ve iş birliği yapmışlardır. II. Mahmut döneminde Tiralizade ailesine asayişi sağlamaları için 1835 yılında “ayanlık" payesi verilmiştir (Yüksel ve Yeşilot, 2012: 149) (Görsel 1). Aile Piraziz'in ihyası için kimi girişimlerde bulunmuştur. Örneğin XIX. yüzyılda ticaretin artmasına paralel olarak Piraziz iskelesinin hareketlendiği bilinmektedir. 1869 yılında Cuma günleri iskelede bir pazar kurulması için bazı girişimler yapılmıştır. Çoğunlukla bir yerde pazar kurulması için Cuma namazı kılınacak camiye ihtiyaç duyulmaktadır. Piraziz'deki cami ihtiyacını Tiralizade Ali Emin Efendi'nin 1870 yılından önce inşa ettirdiği ibadet mekânı karşılamıştır. Amaç cami cemaati içerisindeki kişilerin alışveriş yapması ya da satış yapmasını kolaylaştırmak ve mevcut alana dinamizm katmaktır. Bu girişim, Piraziz iskelesi

\footnotetext{
${ }^{1}$ Bu makale, Necmettin Erbakan Üniversitesi tarafından organize edilen 14-16 Ekim 2021 tarihli 25. Ortaçağ ve Türk Dönemi Kazıları ve Sanat Tarihi Araştırmaları Sempozyumu'nda sunulan bildirinin genişletilmesiyle hazırlanmıştır.

${ }^{2}$ Aslında Tiralizade ailesi 7 konak inşa ettirmiş olup günümüzde biri yıktırılmış ve yerine apartman yapılmıştır.

${ }^{3}$ Karadeniz Bölgesindeki Ayanlar için ayrıca bkz. Bay, 2007; Ekinci, 2013: 15-49; Emecen, 2001.
} 
çevresinde yerleşimi arttırmış, yakın köyler ise merkez niteliği kazanan Piraziz'in mahallesi halini almıştır. XIX. yüzyılda iskele-pazar konumundan kasabaya dönüşen Piraziz, bu dönemde artan dış ticaretten etkilenerek ekonomik gelişim göstermeyi sürdürmüş̧ür. İleriki yıllarda artan nüfusun ihtiyaçları doğrultusunda ticaret, eğitim yapılarında ve dini yapılarda artış görülmüştür (Emecen, 2005: 98-99, 101; Emecen, 2020: 212, 214) (Görsel 2). Tiralizadeler, Tanzimat sonras1 idari değişikliklere (Ortaylı, 2000, Ortaylı, 2018) binaen ortaya çıkmış meclis üyeliği ve belediye reisliği görevlerini üstlenmiş (Emecen, 2005: 101) ya da devletin uygun gördüğü statülere getirilmeyi sürdürmüşlerdir (BOA, DH.MKT, 2455/28, H. 1318) (Görsel 3). Neticede XIX. yüzyıl Osmanlı döneminde ekonomik ve sosyal alanlardaki devinimlerin aktörleri olmuşlardır. Aile üyelerinin günümüzde halen Piraziz’le bağlantıları kesilmemiş olup Cumhuriyet döneminde ve sonrasında edebiyat, siyaset, basın ve benzeri önemli alanlarda isim yaptıkları görülmektedir (Gedikoğlu, 2009, Resuloğlu, 2015).

\section{Tiralizade Konakları}

\section{Tiralizade Hasan Bey Konağı}

Piraziz ilçesinin merkezinde bulunan ve 1908 yılına tarihlenen ${ }^{4}$ Tiralizade Hasan Bey Konağı, Tiralizade Hasan Bey tarafından inşa ettirilmiştir (İltar, 2014: 243). Bodrum üzeri iki katlı olarak inşa edilen konak, kâgir olup kırma çatı ile örtülüdür. Konağın cephe tasarımında Neobarok karakterin yoğun olarak tercih edildiği eklektik bir görünüm takip edilebilmektedir. Geniş bir avlu içerisinde yer alan konağın ana giriş kapısı güney cephede yer almaktadır. Zemin ile birlikte üç katlı bir görünüm sergileyen cephe birinci kattan itibaren köşe pilastrlarıyla ve bezemeli korniş üzeri konsollarla desteklenen yüzeyi silmelerle hareketlendirilmiş saçak ile çevrelenmektedir. Katlar birbirinden yoğun profilli silmelerle ayrılmıştır. Eksene simetrik olarak düzenlenen cephenin birinci katının ortasında yer alan giriş kapısına, zeminin eksenine yakın noktadan başlayan ve "C" kıvrımı şeklinde sahanlığa ulaşan iki kollu merdiven ile erişilmektedir. Merdiven sahanlığının alt kısmı sahanlık seviyesine kadar taşırılmış olup buraya zemin kata girişi sağlayan bir kapı açıklığı ile iki yanına birer pencere açıklığı verilmiştir (Görsel 4-7). Birinci katta, sahanlığın köşelerine yerleştirilen korint tarzı başlıklara sahip sütunların karşısına yukarıya doğru genişleyen silmeli başlıklara sahip gömme sütunlar yerleştirilerek burası bir sundurma şeklinde düzenlenmiştir. Korint tarzındaki sütunların tüm kısımlarında yoğun bezeme unsurları göze çarpmaktadır. Kaide kısmı bombeli ve yukarıya doğru daralarak profilli bir çanak şeklinde sonlanmakta olup yüzeyinde akant yaprakları ve dal motifleri yer almaktadır. Gövde kısmı ise aşağıdan yukarıya doğru sırayla stilize bitki kıvrımları ile püskül motifli, spiral şeklinde, iri akant yapraklarından geliştirilen bitkisel dekorlu ve yivli beş ayrı düzenlemeye sahiptir. Sundurma ikinci katta balkon şeklinde devam etmektedir. Bu kompozisyonda eksene yerleştirilen kapı çift kanatlı olup profilli silmelerle çevrelenmiştir. Kapının iki yanında üzeri friz ve düz alınlıkla sınırlandırılan dikdörtgen formlu pencere açıklıkları mevcuttur. Alınlıkların üzerinden merkeze doğru yükselen kornişlerle kapı

\footnotetext{
${ }^{4}$ Hasan Tirali, Hasan Bey Konağının yapımına 1904-1905 yılında başlanıp 1908 yılında tamamlandığını ifade etmiştir. Görüşme tarihi: 16.09.2021.
} 
üzerinde bir üçgen alınlık oluşturulmuştur. Katın yanlarda kalan cephelerine ise lentolu, düz alınlıklı ikişer giyotin pencere açıklığı yerleştirilmiştir. İkinci katta yer alan balkon üç yönden korkuluklarla çevrelenmiştir. Balkona açılan kapı iki kanatlı olup üst kenarı yüzeyi silmelerle hareketlendirilen basık yuvarlak kemerle sınırlandırılmıştır. Kemer kilit taşı iri bir akant yaprağı motifiyle vurgulanmıştır. Kapının iki yanında yer alan yivli gövdeli, korint başlıklı gömme sütunların üzerine yüzeyden taşırılmış düz bir alınlık oturtulmuştur. Profilli silmelerden oluşan alınlığın alt kenarı üçgen ve alt kenarına yarım yuvarlak sarkıtlar eklenmiş karelerin atlamalı olarak dizilmesiyle oluşturulmuş bir şerit şeklinde düzenlenmiştir. Alınlığın üzerinde, iki yanda gömme sütunların üzerinde yükselen akant yaprağı detaylı birer fiyale ortada ise kırık alınlıklı bir kitabelik bölümü yer almaktadır. Yukarıya doğru genişleyen iki kademeli bir platform üzerine yerleştirilen, yanları ve üzeri iri yaprak motifi ile hareketlendirilen kitabe panosu, iki kanat şeklinde düzenlenmiş olup günümüzde yüzeyi boştur. Kapının iki yanında dar tutulmuş dikdörtgen formlu birer pencere açıklığı mevcuttur. Pencerelerin üzerinde içe doğru kademeli olarak girintilenmiş birer kartuş bulunmakta olup kartuşların yüzeylerine birer girland motifi yerleştirilmiştir. Eksendeki alınlık, pencerelerin dış kenarlarının üst kısmında da devam etmekte olup bunlar alttan profilli konsollarla desteklenmiştir. Alınlıklarla aralarında kalan bölümlere silmeli birer yuvarlak kemer oturtularak pencerelerin üzerinde dekoratif bir görünüm oluşturulmuştur. Kemerlerin kilit taşları konsol ve stilize palmet motifleriyle hareketlendirilmiştir. Katın kalan cephelerinde alttakilerle aynı hizaya konumlandırılan giyotin pencere açıklıkları mevcuttur. $\mathrm{Bu}$ pencereler yanlardan sütunçelerle sınırlandırılmış olup profilli kırık alınlıklarla sonlanmaktadır. Üst sövelerine ince girland motifleriyle püsküller yerleştirilen pencerelerin alınlıklarının kırık kısmında bodur birer fiyale, alt kenarında ise kapı alınlığı altında yer alan atlamalı dizinin tekrarı yer almaktadır. Alt kenarı ok ucu dizisi şeklinde düzenlenmiştir. Alt köşelerinde ise sütunçeleri destekleyen birer konsol da bulunmaktadır. Konağın kuzey cephesi eksendeki uygulama ve pencerelerdeki bazı farklılıklar dışında güney cepheyle aynı tasarıma sahiptir. Burada birinci katın ekseninde yer alan giriş kapısına batıdan yükselen tek kollu merdivenle ulaşılmaktadır. Çift kanatı kapı içeriye doğru daralan kademeli silmelerin içerisine yerleştirilmiş olup iki yanında dar dikdörtgen formlu birer pencere açıklığına yer verilmiştir. Pencere açıklıkları üzerinde düz bir şekilde yer alan alınlık ise kapı hizasında yukarıya doğru uzatılarak birleştirilmiş ve üçgen oluşturmuştur. Bu alınlığın üzerine kapının yan sövelerinin hizasına korint tarzı sütun başlığ yerleştirilmiştir. İkinci katta ise güney cephede balkonun yer aldığı bölgede üç adet pencere açıklığına yer verilmiş olup yandaki pencereler daha dar tutulmuştur. Cephenin tüm katlarında yer alan pencereler güney cephenin kat-pencere tasarımıyla benzer şekilde düzenlenmiştir. Tek farkları ise ikinci kattaki pencerelerin üst sövesinde girland yerine tercih edilen iç içe geçmiş zincir motifleridir. Konağın doğu cephesi de diğer cephelerle benzer bir kompozisyona sahiptir. Buradaki farklılıklar ise güney cephede eksende yer alan kapı ve sundurma-balkon düzenlemesinin yerine pencere açıklıklarına yer verilmiş olması ve eksenin cumba şeklinde düzenlenmesidir. Batı cephe diğer cephelere göre daha sade tutulan ve simetrik olmayan bir görünüm sergilemektedir. Birinci katta diğer cephelerin birinci katında görülen pencere tasarımı tekrar edilerek eksende ikiz ve eksenin güneyine tekli açıklık biçiminde 
düzenlenmiştir. İkinci katta ise alt kat pencerelerinin hizasına yine diğer cephelerin ikinci katında yer alan pencerelerle aynı tasarıma sahip bir ikiz bir de tekli pencere açıklığı konumlandırılmıştır (Görsel 8-11).

\section{Tiralizade Halis Bey Konağı}

Piraziz ilçesindeki Tiralizade Halis Bey Konağı, 1919 yılına tarihlenmekte olup Tiralizade Ali Ağa Oğlu Halis Bey tarafından inşa ettirilmiştir (İltar, 2014: 247). Bugün harap durumda olan konak bodrum üzeri iki katlı olup, bodrum ve zemin katta yığma taş tekniği, birinci katta ise hımış tekniğine başvurulmuştur. Kırma çatı ile örtülü, geniş bir bahçe içerisinde bulunan yapının güney cephesinin zemin katının orta aksında ana giriş kapısı yer almakta olup dikdörtgen formlu, çift kanatlı bu kapının üzerinde bir havalandırma penceresi bulunmaktadır. Kapının her iki yanında metal kanatlarla kapatılan dikdörtgen formlu birer pencere yer almaktadır. Birinci katın orta aksında ise sonradan eklendiği düşünülen bir balkon mevcuttur. Balkonun her iki tarafında aynı boyut ve düzende birer ahşap pencere bulunmaktadır (Görsel 12-13). Yapının kuzey cephesinin bodrum katında dikdörtgen formlu bir kapı ile üç pencere yer almaktadır. Zemin katında aynı boyut ve düzende dikdörtgen formlu dört ahşap pencere görülmektedir. Birinci katın orta aksında ise metal desteklerle taşınan üzeri örtülü bir balkon mevcuttur. Balkonun her iki tarafinda aynı boyut ve düzende iki pencere bulunmaktadır. Yapının batı cephesinde zemin ve birinci katına dek uzanan, üzerinde farklı boyut ve düzende pencerelere sahip bir çıkma görülmektedir. Yapının doğu cephesinde ise deformasyon ve bitkilenme nedeniyle kapı ve pencere gibi yap1 ögelerinin sahip olduğu özellikler anlaşılmamaktadır. Konağın tüm cephelerinde, katların arası profilli taş silmelerle ayrılmış ve köşeleri de köşe pilastrlarıyla sonlandırılmıştır (Görsel 14-15).

\section{Tiralizade Emin Bey Konağı}

Piraziz ilçesindeki Tiralizade Emin Bey Konağı, 1920-1921 yılına tarihlenmekte olup Tiralizade Ali Ağa Oğlu Emin Bey tarafından inşa ettirilmiştir (İltar, 2014: 250). Bugün yarı yıkılmış durumda olan konak, bodrum üzeri iki katlı olup kâgir özelliktedir. Kırma çatı ile örtülü yapının harap duruma gelmeden önceki fotoğraflarından hareketle güney cephesinde zemin katın orta aksında lento ve söveleri taş olan basık kemerli formda çift kanatlı giriş kapısı yer almaktadır. Kapının iki tarafında basık kemerli formda birer pencere vardır. Birinci katta da dikdörtgen formlu iki ahşap pencere mevcuttur. Yapının doğu cephesinin ortasında bodrum katından birinci kata dek uzanan bir çıkma görülmekte olup çıkmanın bulunduğu katların cephelerine pencereler yerleştirilmiştir. Batı cephesinin bodrum katında küçük bir kapı, zemin ve birinci kat cephesinde ise farklı hizalarda olan pencereler yerleştirilmiştir Yapının kuzey cephesinin bodrum katında dikdörtgen formlu iki havalandırma penceresi bulunmaktadır. Birinci katında ise dikdörtgen formlu, ahşap kanatla kapatılmış beş pencere görülmektedir. İkinci katın orta aksında metal desteklerle taşınan, duvarları yıkılmış haldeki bir cumba ve cumbanın her iki yanında lento ve söveleri ahşap olan dikdörtgen formlu ikişer pencere mevcuttur (İltar, 2014: 250) (Görsel 1619). 


\section{Tiralizade Hüseyin Bey Konağı}

Piraziz ilçesindeki Tiralizade Hüseyin Bey Konağı, 1920-1922 y1lına tarihlenmekte olup Tiralizade Ali Ağa Oğlu Hüseyin Bey tarafından inşa ettirilmiştir (İltar, 2014: 248). Yapının cepheleri Neoklasik üslupta tasarlanmıştır. Bodrum üzeri iki katlı yapı, kâgir olup kırma çatı ile örtülüdür. Geniş bir bahçe içerisinde bulunan yapının doğu cephesinin zemin katının orta aksında ana giriş kapısı yer almakta olup dikdörtgen formlu, çift kanatlı bu kapının lento ve söveleri profillidir. Lento üzerinde akant yaprağı kabartma şeklinde görülmekte olup kapı çerçevesi üçgen bir alınlıkla sonlandırılmıştır. Kapının bitişiğinde dikdörtgen formda uzatılmış birer pencere bulunmaktadır. Giriş kapısı ve bu pencereler en dışta dor nizamlı sütunçeler ile sınırlandırılmış olup bu ögelerin her iki yanında metal kanatlarla kapatılan dikdörtgen formlu, birer ahşap pencere yer almaktadır. Birinci katın ekseninde ise sonradan eklendiği düşünülen bir balkon mevcuttur. Balkonun her iki tarafında aynı boyut ve düzende birer pencere açılmıştır. Yapının batı cephesinde zemin ve birinci katına dek uzanan, üzerinde farklı boyut ve düzende pencerelere sahip bir çıkma görülmektedir. Tüm cephelerde, katların arası yoğun profilli taş silmelerle ayrılan yapının köşeleri de yer yer dor nizamlı sütun başlığıyla hareketlendirilmiş köşe pilastırlarıyla sonlandırılmıştır. Yapının batı cephesinin bodrum katından birinci katına dek devam eden üzerinde küçük havalandırma pencerelerine sahip bir çıkma cepheye hareketlilik katmıştır. Batı cephenin zemin ve birinci katına, farklı noktalarda yer alan ve diğer cephelerdeki pencerelerle aynı özelliklere sahip pencereler yerleştirilmiştir (Görsel 20-22). Yapının kuzey cephesinin bodrum katında dikdörtgen formlu dört pencere yer almaktadır. Zemin katında ve birinci katında ise armudi formlu, kaideleri süslü tutulmuş dor nizamlı sütunlarla taşınan bir çıkma görülmektedir. Çıkmanın her iki katta da önünde ikişer ve yanlarında dikdörtgen formlu birer pencere yer almaktadır. Bahsedilen iki katta çıkmanın her iki tarafında aynı boyut ve düzende ikişer pencere görülmektedir. Pencerelerin lentoları genel olarak profilli tutulmuş olup denizlik köşeleri dor nizamlı sütun başlığı biçimindeki konsollarla sınırlandırılmıştır. Yapının güney cephesinin bodrum katının orta aksında dikdörtgen formlu bir kapı ile kapının her iki yanında küçük boyutlu birer havalandırma penceresi görülmektedir. Zemin ve birinci katta ise aynı hizada ve aynı boyut ve düzende üçer pencere bulunmaktadır. Konağın tüm cephelerinde, katların arası profilli taş silmelerle ayrılmış olup köşeleri de dor nizamlı sütun başlıklarıyla hareketlendirilmiş köşe pilastrlarıyla sonlandırılmıştır.

\section{Tiralizade Behçet Bey Konağı}

Piraziz ilçesindeki Tiralizade Behçet Bey Konağı, 1921-1922 yılına tarihlenmekte olup Süleyman Ağa Oğlu Behçet Bey tarafından inşa ettirilmiştir (İltar, 2014: s. 246). Geniş bir bahçe içerisinde bulunan bodrum üzeri iki katlı yapı, yarı kâgir olup kırma çatı ile örtülüdür. Konağın cephelerinde genel itibariyle geleneksel tasarıma bağlı kalınmış olup süsleme ve pencere detaylarında Neoklasik etki görülmektedir. Restorasyon görmüş yapının batı cephesinde zemin katın orta aksında ana giriş kapısı yer almakta olup buraya merdiven ile ulaşılmaktadır. Dikdörtgen formlu, çift kanatı kapının lentosu üzerinde akant yapraklı kabartma bir motif bulunmaktadır. Kapının her iki tarafında dikdörtgen 
formlu, ikişer pencere yer almaktadır. Birinci katın orta aksında ise tek penceresi bulunan bir cumba mevcuttur. Cumbanın her iki tarafına aynı boyut ve düzende yarım kemerli formda birer ahşap pencere yerleştirilmiştir (Görsel 23-24). Yapının doğu cephesinde bodrum katından birinci katına dek sonradan eklendiği anlaşılan ve üzerinde küçük pencereler açılmış bulunan bir çıkma mevcuttur. Kuzey cephesinin bodrum katında dikdörtgen formlu bir kapı ile üç pencere yer almaktadır. Zemin katında aynı boyut ve düzende dikdörtgen formlu dört ahşap pencere mevcuttur. Birinci katın orta aksında ise bat1 cephenin birinci katında görülen cumbayla aynı özelliklere sahip bir cumba daha görülmektedir. Cumbanın her iki tarafında aynı boyut ve düzende yarım daire kemerli formda iki pencere bulunmaktadır. Yapının güney cephesinin zemin katına dikdörtgen formda iki, birinci katına ise yarım daire kemerli formda üç pencere yerleştirilmiştir. Tüm cephelerde, katların arası profilli mermer silmelerle ayrılan yapının köşeleri de köşe pilastrlarıyla sonlandırılmıştır (Görsel 25-26).

\section{Tiralizade Osman Bey Konağı}

Piraziz ilçesindeki Tiralizade Osman Bey Konağı, 1926 yılına tarihlenmekte olup Tiralizade Ali Ağa Oğlu Osman Bey tarafından inşa ettirilmiştir (İltar, 2014: 245). Bodrum üzeri iki katlı, yarı kâgir yapı, kırma çatı ile örtülü bir yapıdan ibarettir. Geniş bir bahçe içerisinde bulunan yapının birinci kat cephelerinde Neoklasik bir anlayış takip edilirken ikinci katın cephelerinde geleneksel bir anlayış hâkim olmuştur. Güney cephenin zemin katının ekseninde ana giriş kapısı yer almakta olup buraya bir merdiven ile ulaşılmaktadır. Dikdörtgen formlu, çift kanatlı giriş kapısının üzerinde bir havalandırma penceresi bulunmaktadır. Kapının her iki yanında metal kanatlarla kapatılan dikdörtgen formlu ikişer ahşap pencere yer almaktadır. Birinci katın ekseninde ise önde iki, yanlarda bir penceresi bulunan bir cumba mevcuttur. Üçgen alınlıkla sonlandırılmış olan cumbanın her iki tarafında aynı boyut ve düzende dikdörtgen formlu iki ahşap pencere yer almaktadır. Yapının kuzey cephesinde bodrum katından birinci katına dek sonradan eklendiği anlaşılan çıkmalar mevcuttur. Cephenin her iki katında farklı düzen ve boyutta ahşap pencereler açılmıştır (Görsel 27-28). Konağın doğu cephesinin bodrum katında dikdörtgen formlu bir kapı, zemin katında ise aynı boyut ve düzende metal kanatlarla kapatılmış dikdörtgen formlu dört ahşap pencere yer almaktadır. Birinci katın orta aksında ise önde iki, yanlarda tek penceresi bulunan bir cumba görülmektedir. Güney cephedeki cumba gibi üçgen alınlıkla sonlandırılmış olan cumbanın her iki tarafında aynı boyut ve düzende dikdörtgen formlu iki pencere bulunmaktadır. Yapının batı cephesinde ise herhangi bir açıklık mevcut değildir. Tüm cephelerde, katların arası yatay taş silmelerle ayrılan yapının köşeleri de alçı ve ahşap köşeliklerle sonlandırılmışıı (Görsel 29-30).

\section{Değerlendirme ve Sonuç}

Çalışma konusu kapsamında Piraziz'de Tiralizade ailesi tarafından inşa ettirilen konak yapıları arasında geleneksel tasarımdan kopmayan örnekler olduğu gibi Neobarok ve Neoklasik etkiler gösteren yapılar da tespit edilmiştir. Tiralizade Halis Bey ve Tiralizade Emin Bey konakları bütünüyle geleneksel cephe tasarımını takip eden örneklerdir. Geç Osmanlı döneminde inşa edilmiş Samsun/Alaçam Kitaplı 
Konağ1 (Yılmaz, 2020: 447-485), Sinop/Boyabat Osman Ömeroğlu Evi (Seçkin, vd., 2004: 163), Denizli Paltazade Hacı İsmail Ağa Konağı (Denizli Kültür Envanteri, 2014: 54), Düzce Ömer Kısacık Evi (XX.yy) (Düzce Kültür Envanteri, 2014: 64) konut örnekleri yaygın olarak geleneksel cephe tasarımını yansıtan Anadolu'nun çeşitli kentlerindeki uygulamalar arasında sayılabilirler.

Tiralizade Hasan Bey Konağı, konu kapsamında ele alınan yapılar içerisinde batılılaşma modasını temsil eden en önemli örnek olarak değerlendirilebilir. Yoğun bezeme unsurları, kırık alınlıklar, iri konsollar, püskül, girland ve akant motifleri ile özellikle ana girişe ulaşımı sağlayan merdivenin kıvrımları Neobarok üslubu yansıtan uygulamalardır. Ayrıca eski dönemlere ait fotoğraflardan hareketle bugün var olmayan parapet ve cephe eksenindeki kıvrımlı ahşap ${ }^{5}$ tepelik gibi mimari elemanlar mevcuttur ki bunlar da tasarım açısından Neobarok karakterdedir. Yapının birinci kat cephelerindeki açıklık, alınlık, pilastr uygulamaları ile üç cephesinde tercih edilen eksene simetrik esası Neoklasik üslup niteliğini vurgulayan unsurlar olarak göze çarpar. Bu nitelikleriyle konak, Neobarok etkinin yoğunlukta olduğu Eklektik bir görünüm sergilemektedir (Görsel 31-32). Ordu'nun merkezinde 1896 yılında Paşaoğlu Hüseyin tarafindan İstanbul'dan getirtilen yabancı veya yerel gayrimüslim bir mimara inşa ettirilen Paşaoğlu Konağı (Yıldırım Güneş ve Akın Ertek, 2021: 215-219) da yoğun bezemesi ve cephe tasarımıyla, konağa yakın bir bölgede inşa edilen benzer nitelikli bir yapıdır. Aile üyeleriyle yapılan görüşmeler sırasında bu iki yapının benzerliğine dikkat çekilmiş olup bu benzerliğin aynı mimarın elinden çıkması nedeniyle kaynaklandığı aktarılmıştır. ${ }^{6}$

Aileye ait bir diğer batılı karakterli yapı Tiralizade Hüseyin Bey Konağı'dır. Gerek restorasyon öncesi fotoğraflarından gerekse restorasyon sonrası yapılan incelemelerde yapının tüm cephe tasarımlarında Neoklasik mimarinin klasik blok uygulamasına rastlanılmaktadır. Tiralizade Osman Bey Konağı'nın günümüzdeki cephe tasarımında her ne kadar cumbaların üzerindeki üçgen alınlıklar ve köşe geçişleri batılı etki olarak değerlendirilebilse de genel şemada geleneksel tasarım izlenebilmektedir. Ancak yapıya ait eski fotoğraflarda, ikinci katta yer alan pencerelerin düz alınlıklara sahip olması ve bugünkü ahşap ve alçı köşeliklerin yerine o dönemde gömme sütunların yer alması, konağın orijinalinde geleneksel şemanın yanında Neoklasik üslup çizgisinde batılılaşma dönemi mimari tasarımlarını takip ettiğini göstermektedir. Aynı şekilde Tiralizade Behçet Bey Konă̆ı’nda da kapı girişindeki belirgin kemer kilit taşı ve birinci kat pencerelerinin düz alınlıkları, cumbaların üzerindeki üçgen alınlıklar, kat silmeleri gibi detaylarda Neoklasik üslup izlenirken doğu cephenin ikinci kat pencereleri ve cumbalarda geleneksel cephe tasarımı esas alınmıştır. Bu tarz geleneksel-batılı sentezi tasarımlara Osmanlı’nın

\footnotetext{
${ }^{5}$ Hasan Tirali ile yapılan görüşmeden hareketle Görüşme Tarihi: 16.09.2021

${ }^{6} \mathrm{Bu}$ konu hakkında iki ayrı rivayet bulunmaktadır. Bu rivayetlerden biri söz konusu gayrimüslim mimarın önce Tiralizade Hasan Bey Konă̆ı'nı inşa ettiği, akabinde Paşaoğlu Hüseyin Bey tarafından inşa edilen bu konağın çok beğenilmesi üzerine Ordu'da da bir konak inşasını gerçekleştirdiği şeklindedir. Diğer bir rivayet ise önce Paşaoğlu Konağı'nın inşasından sonra Tiralizade Hasan Bey Konağı'nın inşa edildiğidir. Hatta ikinci rivayete göre Paşaoğlu Hüseyin, sonradan inşa edilen Tiralizade Hasan Bey Konă̆ı'nı gördüğünde kendi konağın tarzında olmasından rahatsızlık duymuştur (Hasan Tirali ile yapılan görüşmeden hareketle Görüşme Tarihi: 16.09.2021). Fakat inşa tarihleri kıyaslandığında Paşaoğlu Konağı'nın önceden inşa edilmiş olduğu anlaşılmaktadır.
} 
batılılaşma dönemine ait konutlarında sıkça rastlamak mümkündür. Bu tasarımlarda genellikle pencere ve kapı çevrelerinde batılı etki söz konusu iken diğer kısımlarda geleneksel uygulamalar takip edilmektedir (Görsel 33-35). Geç Osmanlı döneminde gayrimüslimlerin konut yapılarının cephelerinde Avrupai üslupların yansımalarıyla daha çok karşılaşılmakta olup Müslümanların yaptırdığı konutlarda bahsi geçen üslupların tercih edildiği örneklere ise az rastlanılmaktadır. Bu bakımdan Müslümanların inşa ettirdikleri İstanbul Ragıp Paşa Köşü (1907) (Kuban, 2016: 653-659), İzmir/Konak Katipzade Konağ1 ${ }^{7}$, Trabzon Nemlizade Konağı (1872) ve Kalçığlu Evi (1902-1907) (Karpuz, 2018: 124-125, 133), Ordu Cevat Bey Konağı (1907-1908) (Bayhan, 2017), Denizli Osman Bey Konağı (1903) (Denizli Kültür Envanteri, 2014: 67), Düzce/Akkoca Mehmet Arif Bey Köşkü (XX. yy) (Düzce Kültür Envanteri, 2014: 169) gibi konutların cephe tasarımları detayında Avrupai üslup özellikleri görülmektedir.

Sonuç olarak Tirali ailesinin ilk ayanı Tiralizade Emin Bey’in torunları tarafından yaptırılmış olan bu konaklardan Tiralizade Hasan Bey konağı ilk yaptırılan konut örneği olup bu konuttan sonra inşa ettirilen bazı konakların cephe detaylarında bir etkilenme söz konusu iken diğerlerinde bütünüyle geleneksel tasarım ve uygulamaların tercih edildiği görülmektedir. Hasan Bey Konağının yabancı veya gayrimüslim bir mimarca inşa ettirildiği açıkça anlaşılmakta olup günümüzde ailenin fertleri tarafından da belirtilmektedir. Diğer yapıların ise bölgedeki gayrimüslim usta veya mimarlarca yaptırıldığı ifade edilmektedir. ${ }^{8}$ Konaklarda yabancı mimar ve ustaların çalıştırılması durumu XIX. yüzyıldan itibaren Piraziz'in ticaretle dışa açılmasının (Emecen, 2005: 98-99) etkisiyle paralel olmalıdır. Neticede XIX. yüzyılda dönemin yeniliklerini takip eden ve inşa ettirdikleri yapıları prestij unsuru olarak öne çıkaran Ayan ailesi, inşa ettirdikleri konaklarla şehir kimliğine gösterişli ve özenli yapıları kaydettirmiş aynı zamanda da iktidarın gücünün mimariye yansıması adına dikkat çekici örnekler meydana getirmişlerdir.

Yazar Katkıları: Bu çalışmanın tüm bölümlerinde üç yazar ortak katkı sağlamıştır.

Çıkar Beyanı: Yazarlar arasında çıkar çatışması olmamıştır.

\section{Kaynakça}

Akın, G. (2019). XVIII. - XIX. Yüzyıl Berlin mimarisinde neoklasik üslup (Yüksek Lisans Tezi). Ondokuz Mayıs Üniversitesi Sosyal Bilimler Enstitüsü, Samsun.

Aldrich, M. (2005). Gothic revival. Londra: Phaidon Press.

Andersan, L. (1890). Barock und Rokoko. Münih: Kunst Im Bild, Naturalist Verlag

Atasoy, N. (1985). 17. - 18. Yüzy1llarda Avrupa sanatı. İstanbul: İstanbul Üniversitesi Edebiyat Fakültesi Yayınları.

Bay, İ. (2007). Trabzon eyaletinde mütegallibe hareketleri ve ayanlık (1750-1850) (Doktora Tezi). Atatürk Üniversitesi Sosyal Bilimler Enstitüsü, Erzurum.

\footnotetext{
7 İzmir-Konak'ta bugün Hükümet Konağı'nın bulunduğu alan üzerinde dönemin ayan ailesi Katipzadeler tarafından inşa ettirilen konağın elde edilen eski fotoğraflarından tasarımda Neoklasik ve Neobarok üslupların baskın olduğu eklektik bir yönelim söz konusudur. Fotoğraf için Bkz. https://www.izmirdergisi.com/tr/dergi-arsivi, Erişim Tarihi: 29.11.2021.

${ }^{8}$ Hasan Tirali, yabancı veya gayrimüslim olduğunu belirttiği mimarın seferberlik döneminde buraları terk ettiğini ifade etmiştir. Görüşme Tarihi: 16.09.2021
} 
Bayhan, A. A. (2017). Ordu'da geç Osmanlı sivil mimarlık örneği: Çamaş Cevat Bey Konağı. XX. Uluslararası Ortaçağ Türk Dönemi Kazıları ve Sanat Tarihi Araştırmaları Sempozyumu, 2-5 Kasim 2016, Sakarya, 62-78.

Blunt, A. (1988). Baroque and rococo architecture and decoration. Hertfordshire: Wordsworth Editions.

Bony, A. (2012). L'Architecture moderne. Paris: Larousse.

Bouillon, J.P. (1985). Journal de L'Art Nouveau. Paris: Skira.

Briggs, M. S. (1914). Baroque architecture. New York: McBride-Nast \& Company.

Clark, K. (1983). The Gothic revival: An essay in the history of taste. Londra: John Murray.

Çelik, Z. (1986). 19. Yüzyılda Osmanlı başkenti. İstanbul: Ekonomi ve Toplumsal Tarih Vakfı.

(2014). Denizli kültür envanteri. Denizli Büyükşehir Belediyesi.

(2014). Düzce kültür envanteri. Düzce Valiliği İl Kültür ve Turizm Müdürlüğü.

Duncan, A. (1994). Art Nouveau, World of Art. New York: Thames and Hudson.

Eastlake, C. L. (2012). A history of the gothic revival. Cambridge: Cambridge University Press.

Ekinci, İ. (2013). Karadeniz'de ayanlar ve denizcilik. Karadeniz Araştırmaları, (37), 15-49.

Emecen F. M. (2001). Doğu Karadeniz'de ayanlık; Tirebolulu Kethüdazâde Mehmet Emin Ağa. Belleten Dergisi, LXV (242), 193-215.

Emecen, F. M. (2005). Doğu Karadenizde iki kıyı kasabasının tarihi: Bulancak-Piraziz. İstanbul: Kitabevi.

Emecen, F. M. (2020). Piraziz tarihine giriş: Abdal İskelesi’nden Piraziz’e. Karadeniz Kıyı Kentleri Tarihi Turkuvaz Kitap.

Englund, S. (2004). Napoleon: A political life. New York: Scribner.

Fatsa, M. (2008). Giresun yöresinde Osmanlı vakıfları ve vakıf eserler (Dini-İlmi Hayat ve Sosyal Kurumlar). Giresun: Giresun Belediyesi Yayınları.

Fredlund, J. (2008). Stilguiden: Möbler \& Inredning 1700-2000. Stockholm: Prisma.

Gedikoğlu, Y. G. (2009). Naim Tirali’nin öykücülüğü (Yüksek Lisans Tezi). Gaziantep Üniversitesi Sosyal Bilimler Enstitüsü, Gaziantep.

Germann, G. (1972). Gothic revival in Europe and Britain: Sources, influences and ideas. Londra: Lund Humphries.

Hitchcock, H. R. (1958). Architecture nineteenth and twentieth centuries. The Pelican History of Art. Londra: Penguin Books.

Honour, H. (1977). Neo-classicism style and civilisation. Londra: Penguin Books.

İltar, G. (2014). Giresun kültür envanteri. İstanbul: Dönence Basım ve Yayın.

Karpuz, H. (2018). Trabzon merkez ve ilçelerindeki önemli tarihi yapılar. Ankara: Türk Tarih Kurumu.

Kuban, D. (2016). Osmanlı mimarisi. İstanbul: Yem Yayınları.

Middleton, R. and Watkin, D. (1980). Neoclassical and 19th century architecture, history of world architecture, Milan: Electa.

Naeuman, R. (2013). Baroque and Rococo Art and Architecture. New Jersey: Pearson Education.

Ortaylı, İ. (2000). Osmanlı İmparatorluğu'nda iktisadi ve sosyal değişim, Makaleler 1. "19. Yüzyılda Trabzon Vilayeti ve Giresun Üzerine Gözlemler" Ankara: Turhan Kitabevi Yayınları.

Ortaylı, İ. (2018). Tanzimat devrinde Osmanlı mahalli idareleri (1840-1880) (3. Bask1). Ankara: Türk Tarih Kurumu Yayınları. 
Özkaya, Y. (2014). Osmanlı İmparatorluğu'nda ayanlık (Genişletilmiş 2. Baskı). Ankara: Türk Tarih Kurumu Yayınları.

Pevsner, N. (1977). Ana çizgileriyle Avrupa mimarlığı. çev. Selçuk Batur, İstanbul: Cem Yayınevi.

Resuloğlu, E. (2015). Naim Tirali’nin hayatı ve eserleri (Yüksek Lisans Tezi). Doğu Akdeniz Üniversitesi Sosyal Bilimler Enstitüsü, Gazimağusa.

Rouge, I. (2008). L'Arc de Triomphe de I'Etoile: Art et Histore. Quetigny Cedex: Faton.

Schulz, C. N. (1979). Baroque architecture. History of World Architecture, Milan: Electa.

Schulz, C. N. (1980). Late Baroque and Rococo Architecture. History of World Architecture, Milan: Electa.

Seçkin, N., Özakın, R., Erdem, A., Yergün, U, Maşalı, D. (2004). Boyabat (Sinop) Kentsel Kültür Varlıkları Envanteri 2003, TÜBA Kültür Envanteri Dergisi, 3, 141-168.

Sümer, F. (1992). Tirebolu tarihi. İstanbul: Etam Matbaa.

Toman, R. (2010). Neoclassicism an romanticism. Potsdam: H. F. Ullmann.

Yıldırım Güneş, Ö ve Akın Ertek, G. (2021). Osmanlı batılılaşmasının Ordu il merkezine yansıması. Tarihi ve Kültürel Boyutlarıyla Ordu II. Ankara: Fenomen Yayıncılık. 215-219.

Y1lmaz, F. (2021). Nüfus mübadelesinin kent dokusuna etkisi ve alaçam evleri (Yüksek Lisans Tezi). Ondokuz Mayıs Üniversitesi Lisansüstü Eğitim Enstitüsü, Samsun.

Yiğitpaşa, N. T. ve Akın Ertek, G. (2020). XVIII. Yüzyıl Berlin kiliselerinde neoklasik üslup. Amisos Dergisi, 5 (8), 219-258.

Yiğitpaşa, N. T. ve Uz, F. (2016). XIX. Yüzyıl Samsun'da bir grup konut mimarisi. Amisos Dergisi. 1 (1), 22-43.

Yüksel, A ve Yeşilot, O. (2012). Giresun'da iz bırakanlar. Giresun: Giresun Valiliğii.

Yüksel, A. (2013). Doğu Karadeniz araştırmaları. İstanbul: Kitabevi Yayınları.

https://www.izmirdergisi.com/tr/dergi-arsivi/338-47-nci-sayi/2794-nereden-geldi-bu-isimler-3.

\section{Arşiv Kaynakları}

BOA, DH.MKT, 2455/28. 


\section{Görseller}

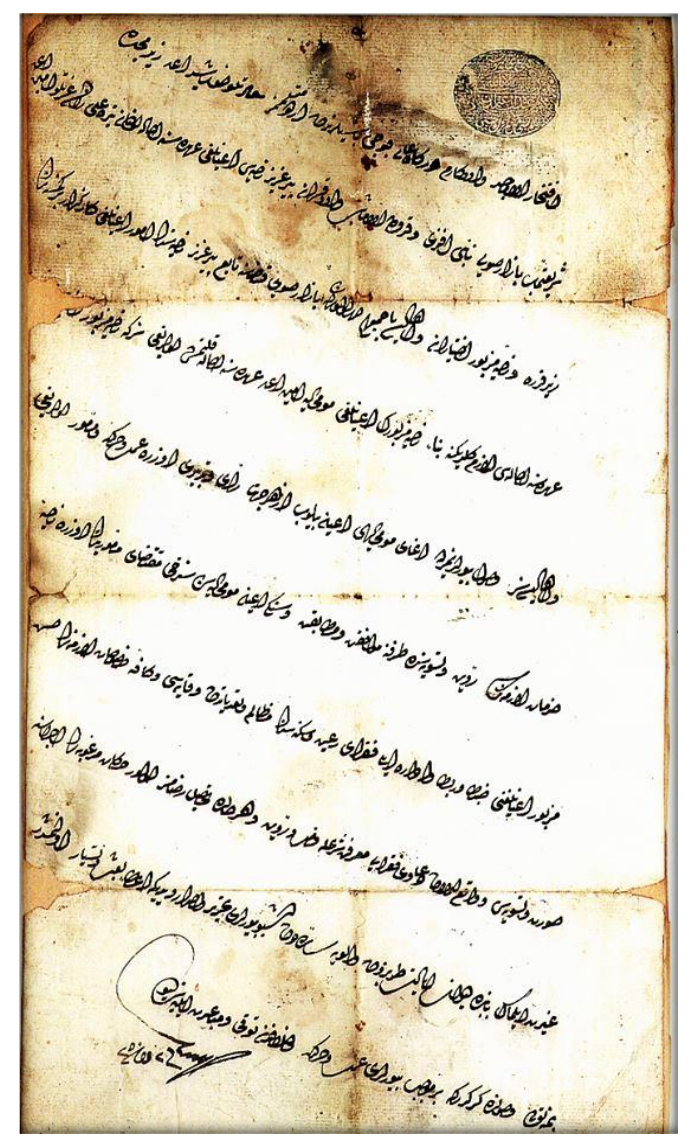

Görsel 1: Tiralizade Ailesine Ayanlık Payesinin Verildiğini Gösteren Berat (Abdullah Tirali’den)

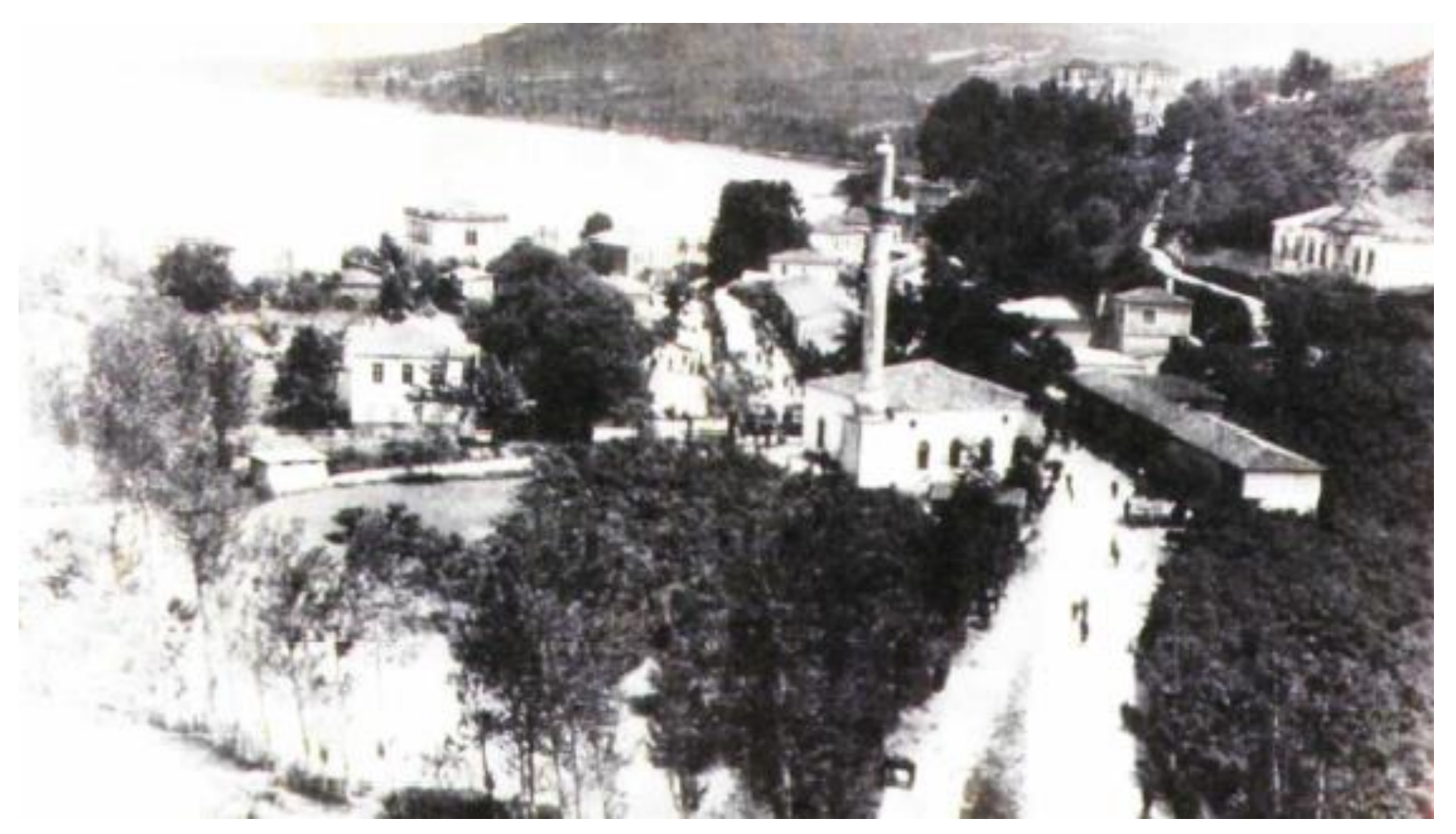

Görsel 2: Piraziz İskele Pazarı Cami (Fatsa, 2008: 47) 


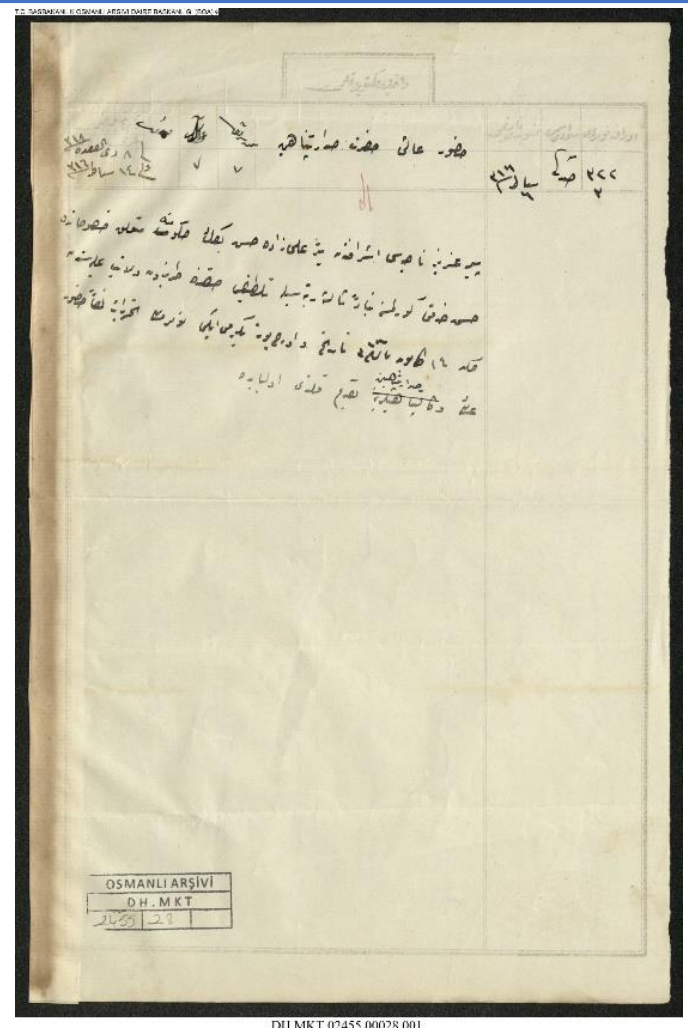

Görsel 3: Trabzon'un Piraziz nahiyesi eşrafından Tir Alizade Hasan Bey'in rütbe ile taltifi (BOA, DH.MKT, 2455/28, H. 1318).
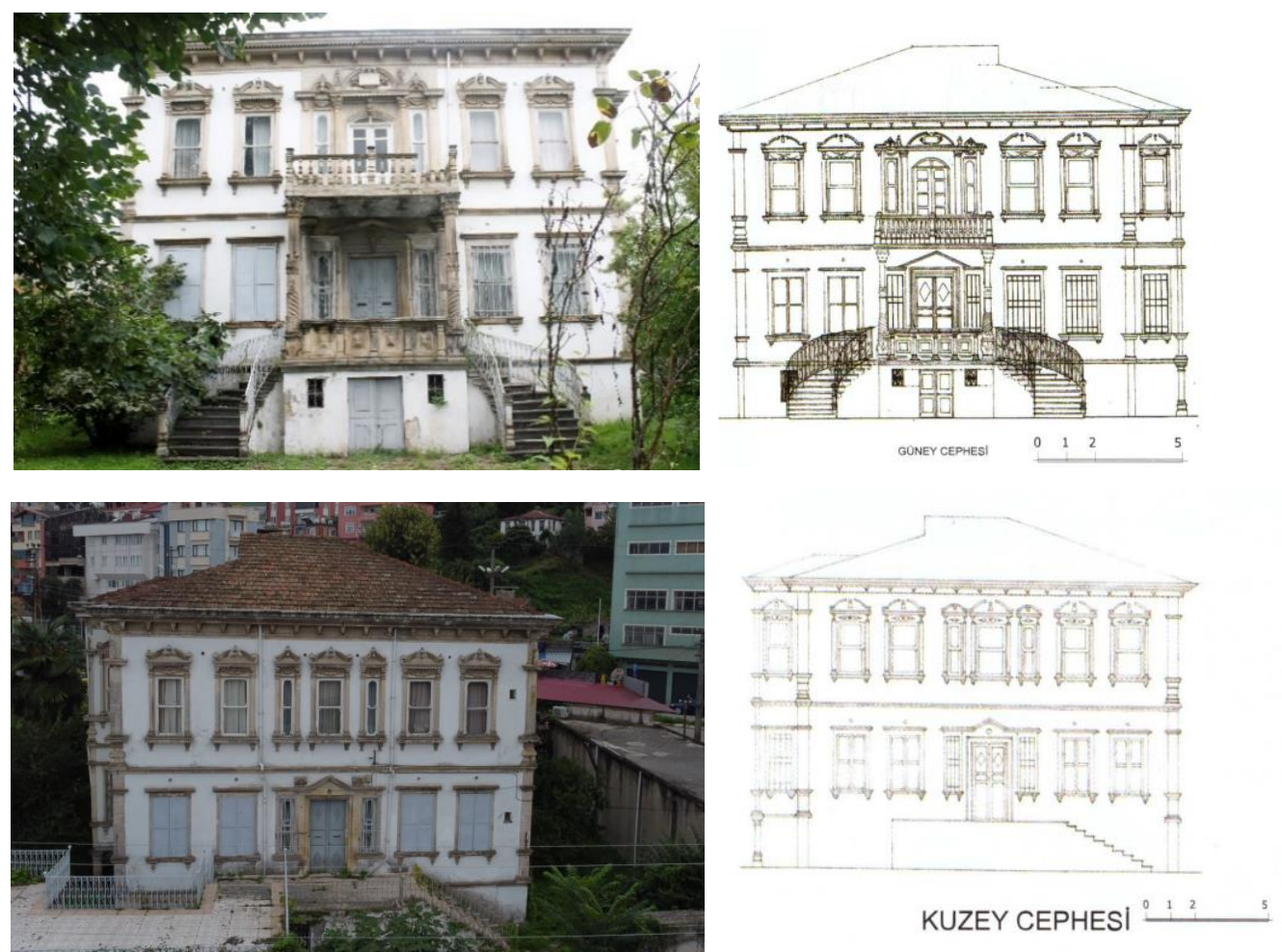

Görsel 4-7: Tiralizade Hasan Bey Konağı Güney ve Kuzey Cephesi (Çizim için Bkz. İltar, 2014: 228) 

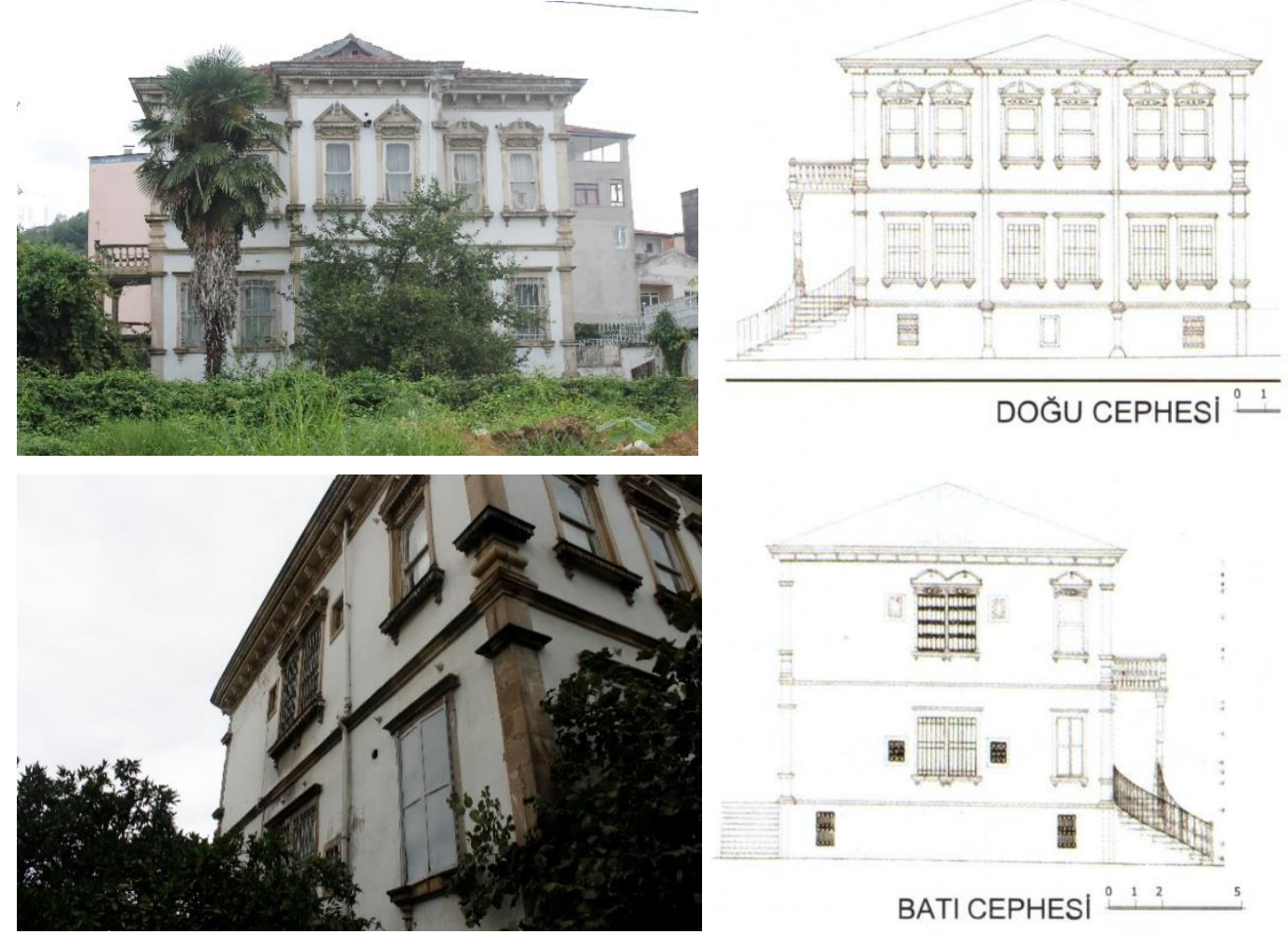

Görsel 8-11: Tiralizade Hasan Bey Konağı Doğu ve Batı Cephesi (Çizim için Bkz. İltar, 2014: 228)

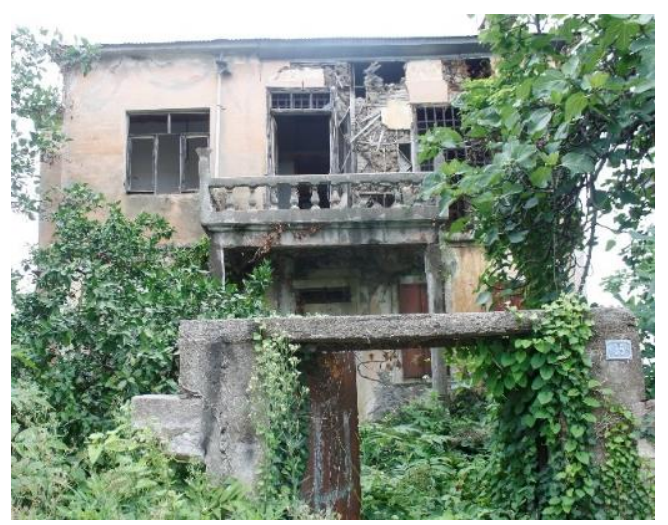

Görsel 12: Tiralizade Halis Bey Konağı Güney Cephesi

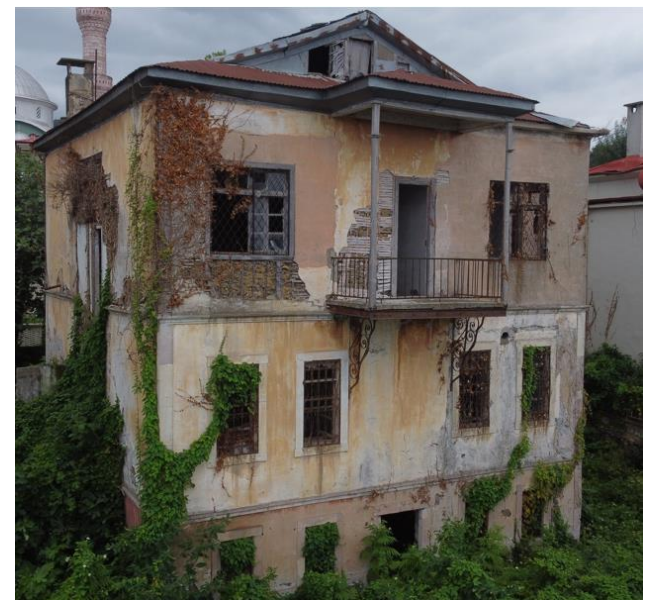

Görsel 13: Tiralizade Halis Bey Konağı Kuzey Cephesi 


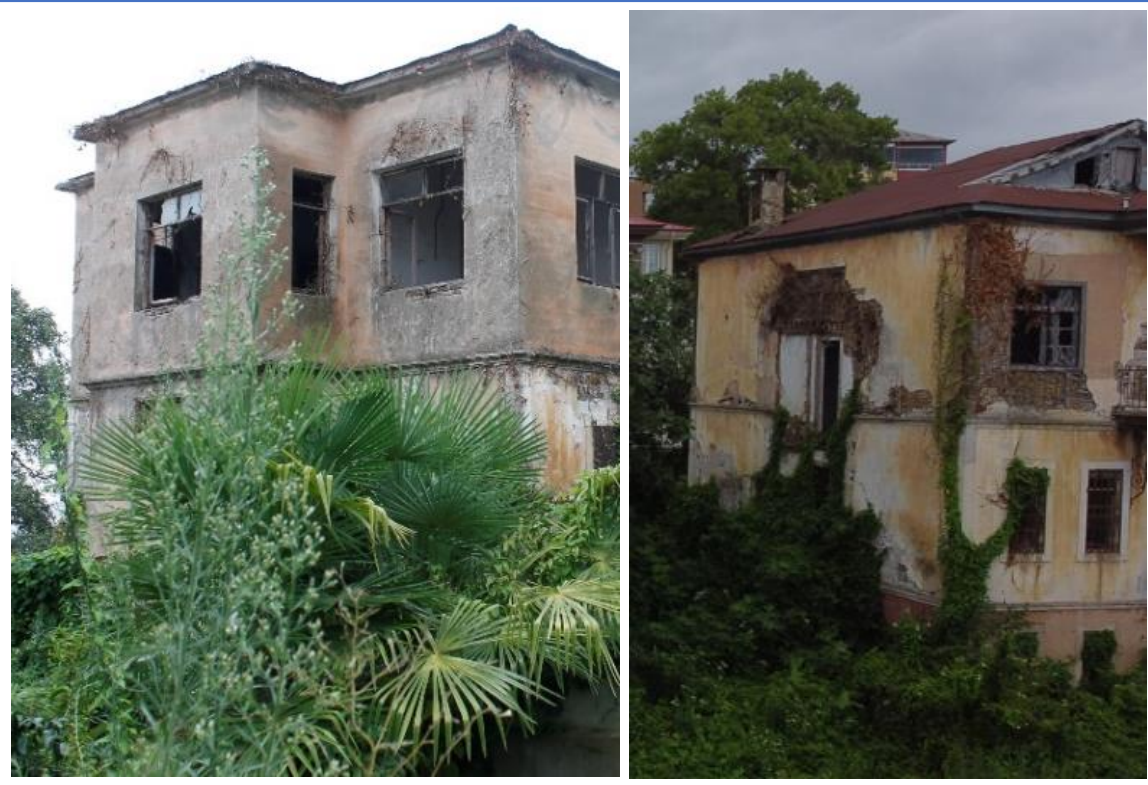

Görsel 14-15: Tiralizade Halis Bey Konağı Batı ve Doğu Cephesi

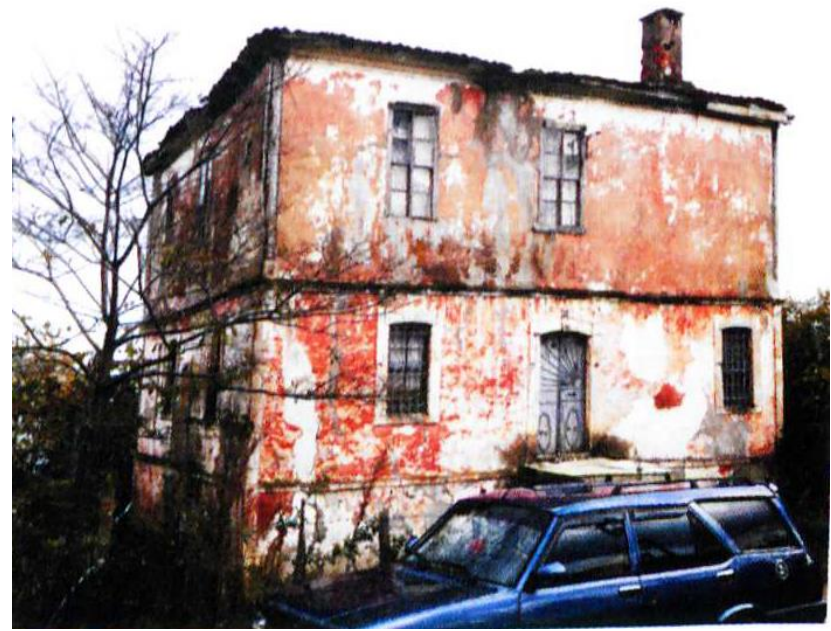

Görsel 16: Tiralizade Emin Bey Konağı Güney Cephesi (İltar, 2014: 250)

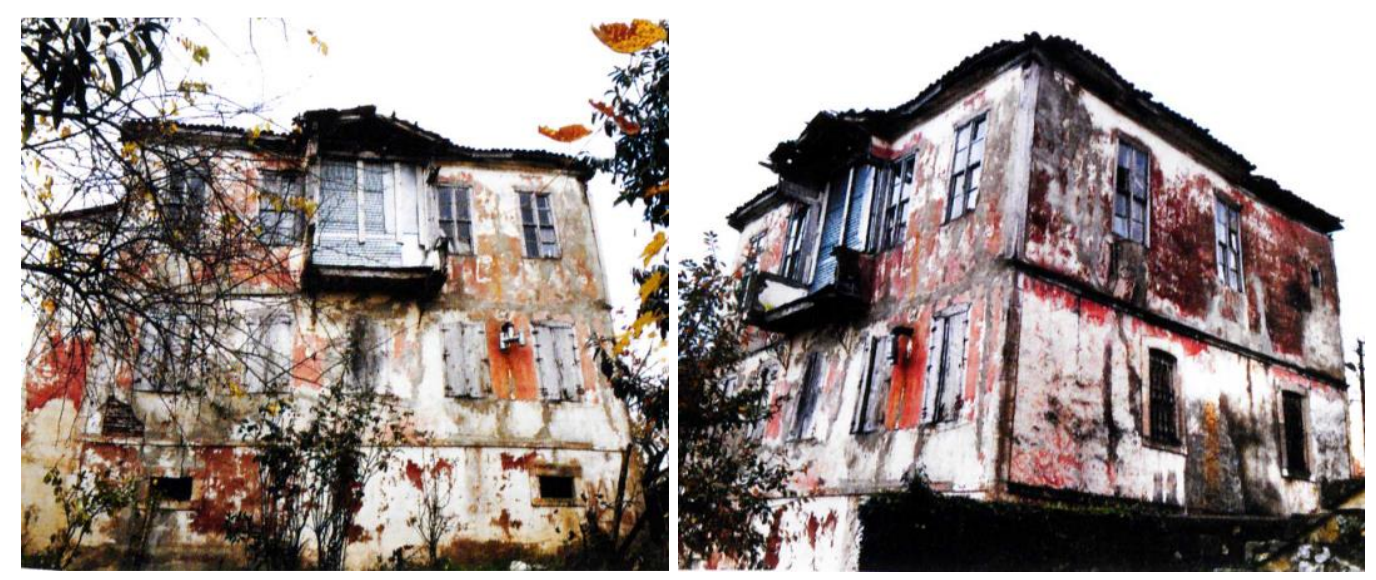

Görsel 17-18: Tiralizade Emin Bey Konağı Kuzey ve Batı

Cephesi (İltar, 2014: 250) 


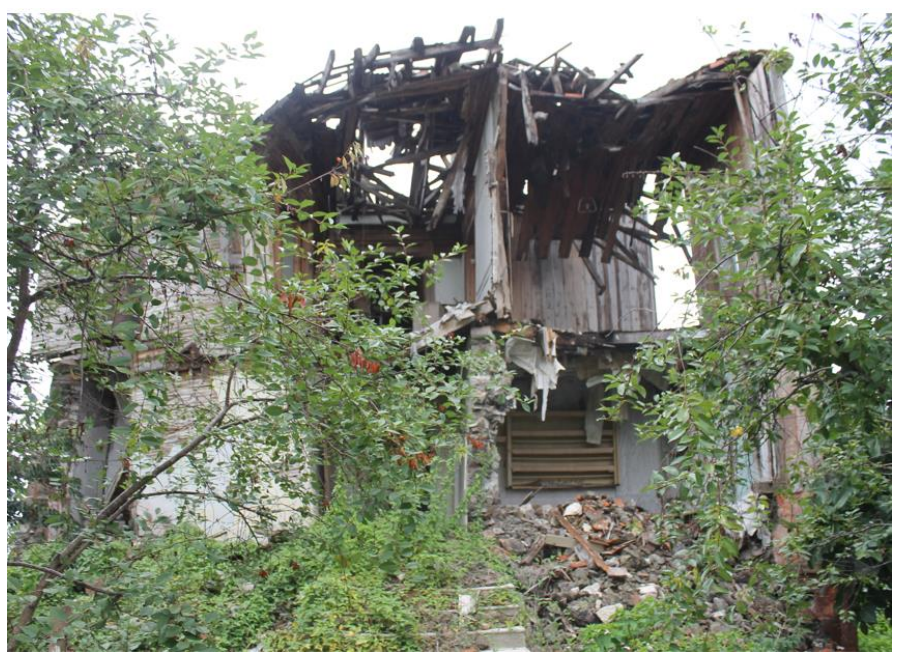

Görsel 19: Tiralizade Emin Bey Konağı Yarı Yıkılmış Hali

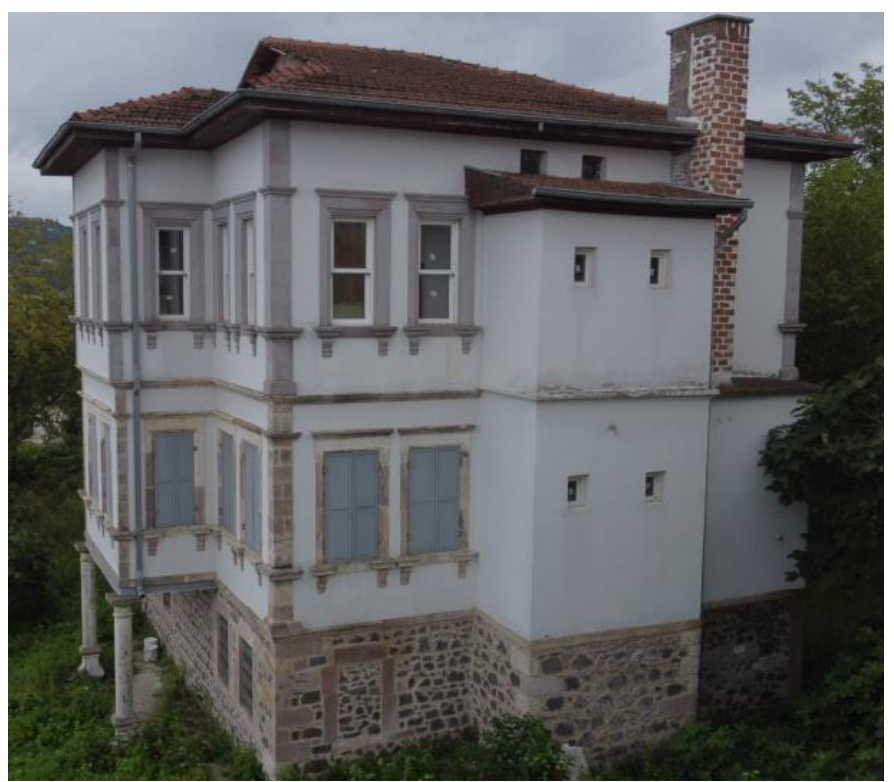

Görsel 20: Tiralizade Hüseyin Bey Konağı Doğu Cephesi
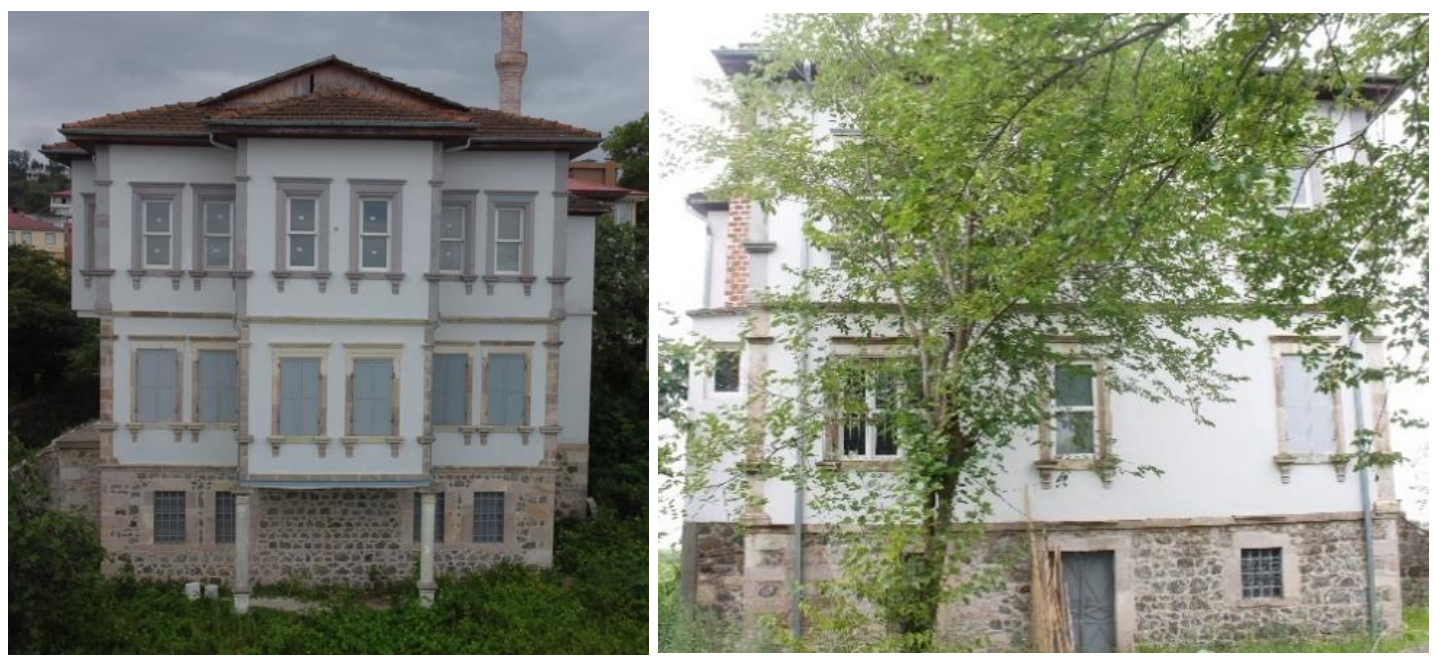

Görsel 21-22: Tiralizade Hüseyin Bey Konağı Kuzey ve Güney Cephesi 


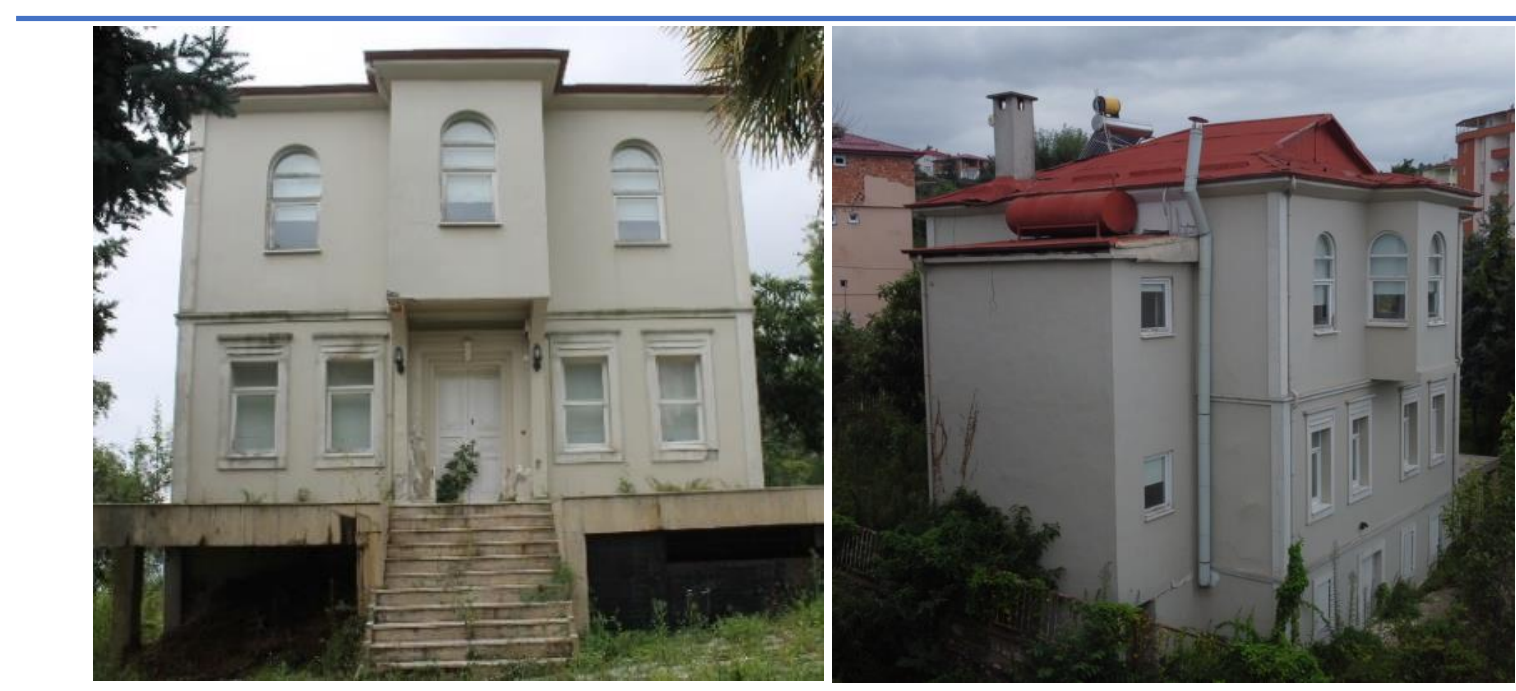

Görsel 23-24: Tiralizade Behçet Bey Konağı Batı ve Doğu Cephesi
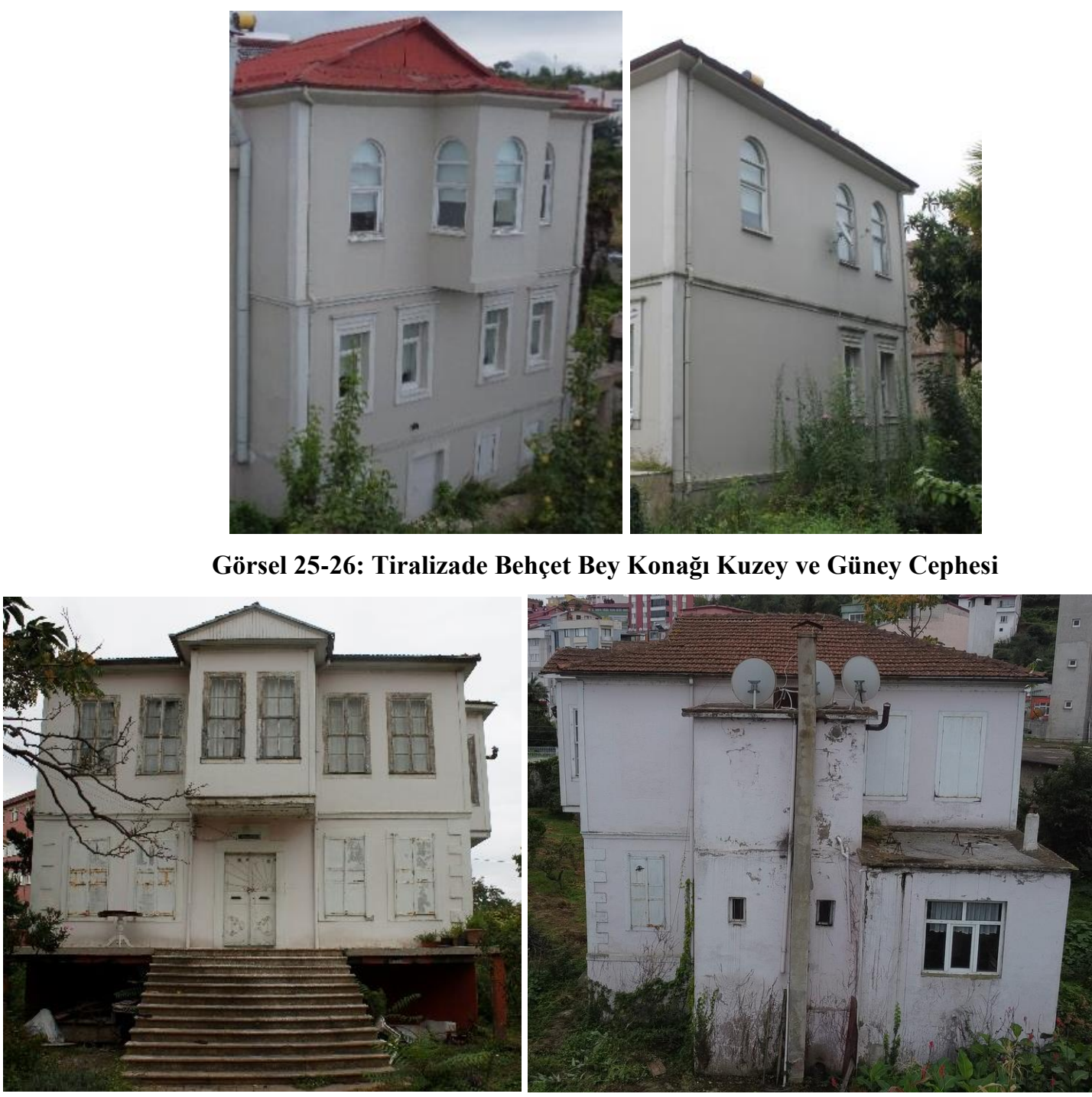

Görsel 27-28: Tiralizade Osman Bey Konağı Güney ve Kuzey Cephesi 

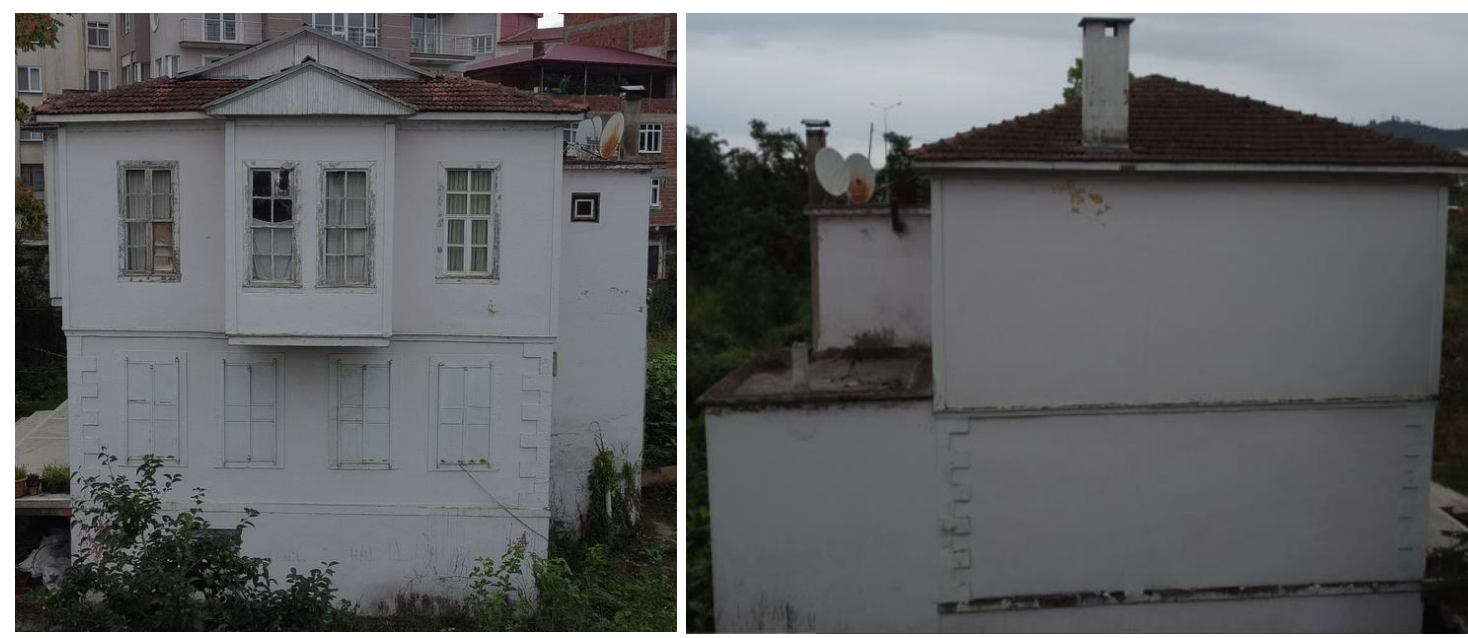

Görsel 29-30: Tiralizade Osman Bey Konağı Doğu ve Batı Cephesi

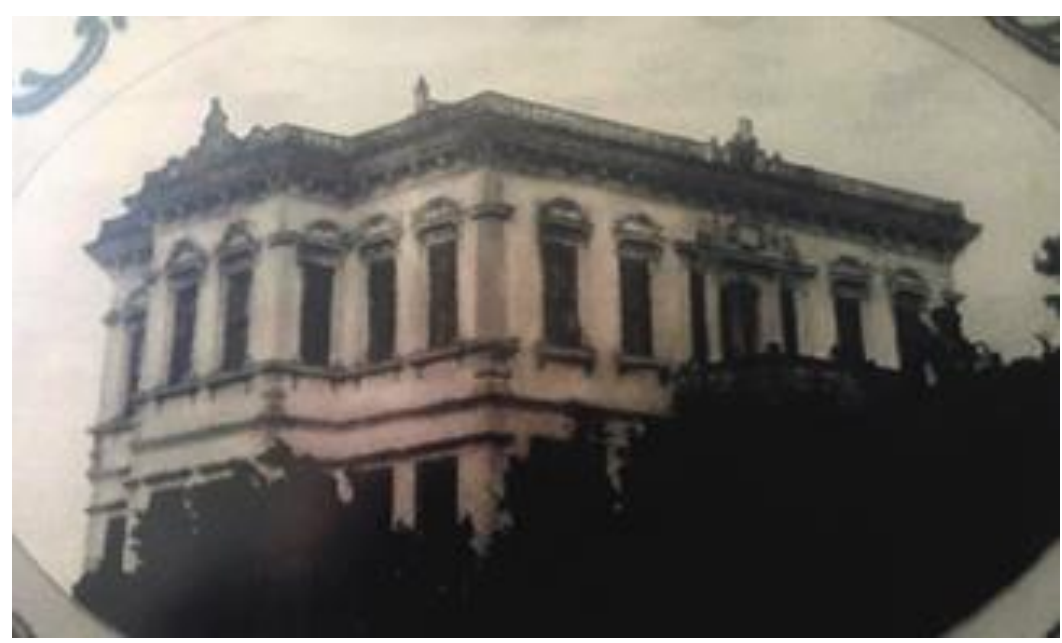

Görsel 31: Tiralizade Hasan Bey Konağı (Hasan Tirali’den)

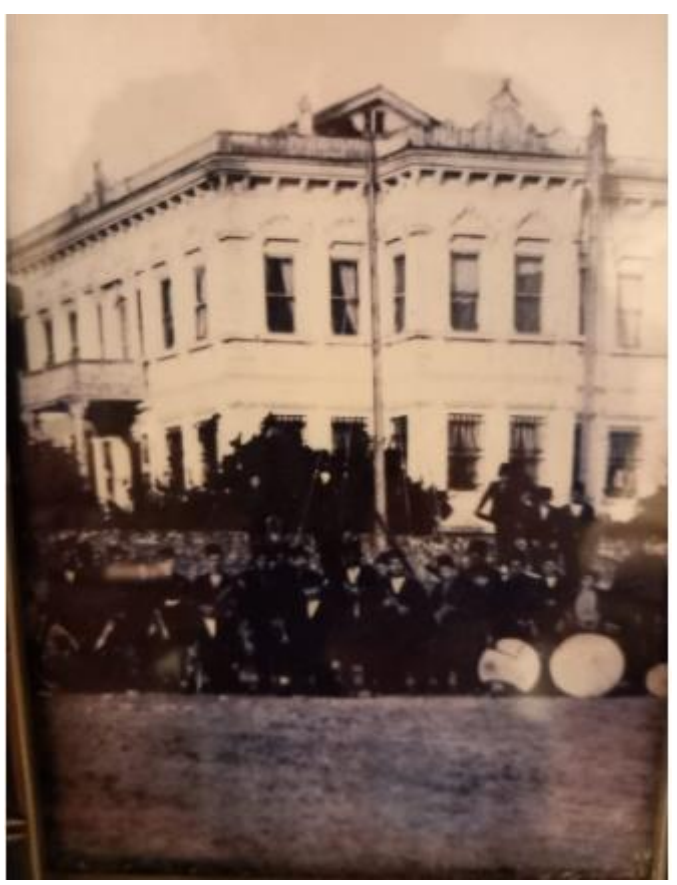

Görsel 32: Tiralizade Hasan Bey Konağı (1924) (Hasan Tirali’den) 


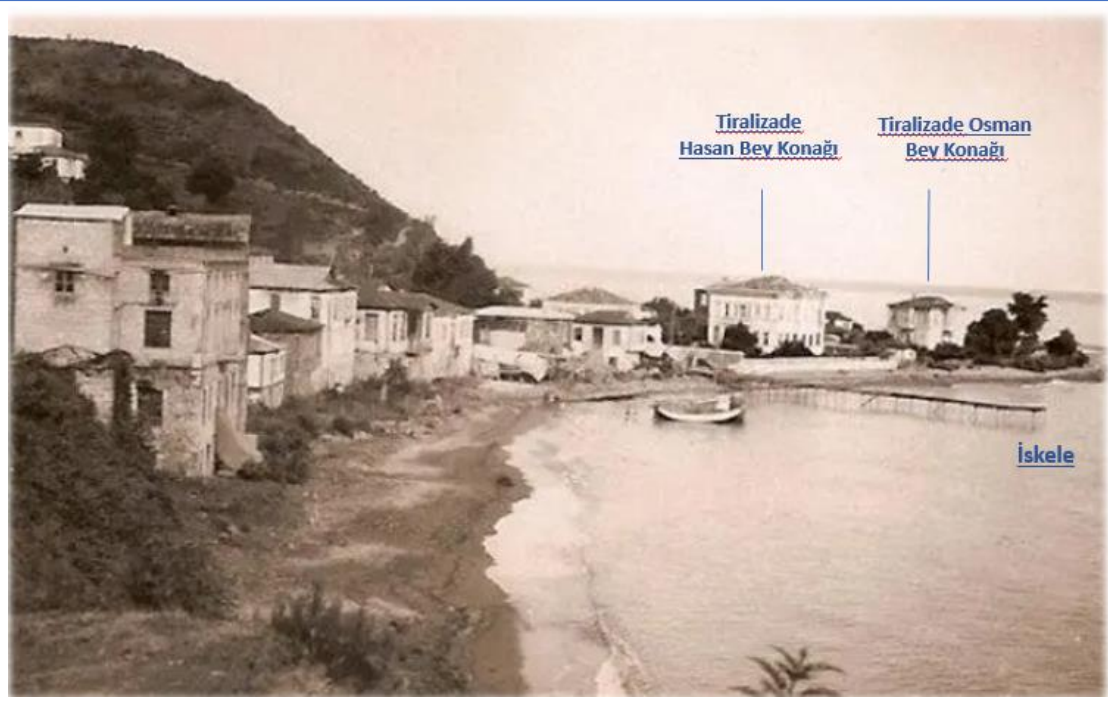

Görsel 33: Piraziz İskelesi ve Tiralizade Hasan Bey ve Osman Bey Konağı 1937 (Emecen, 2020: 213)

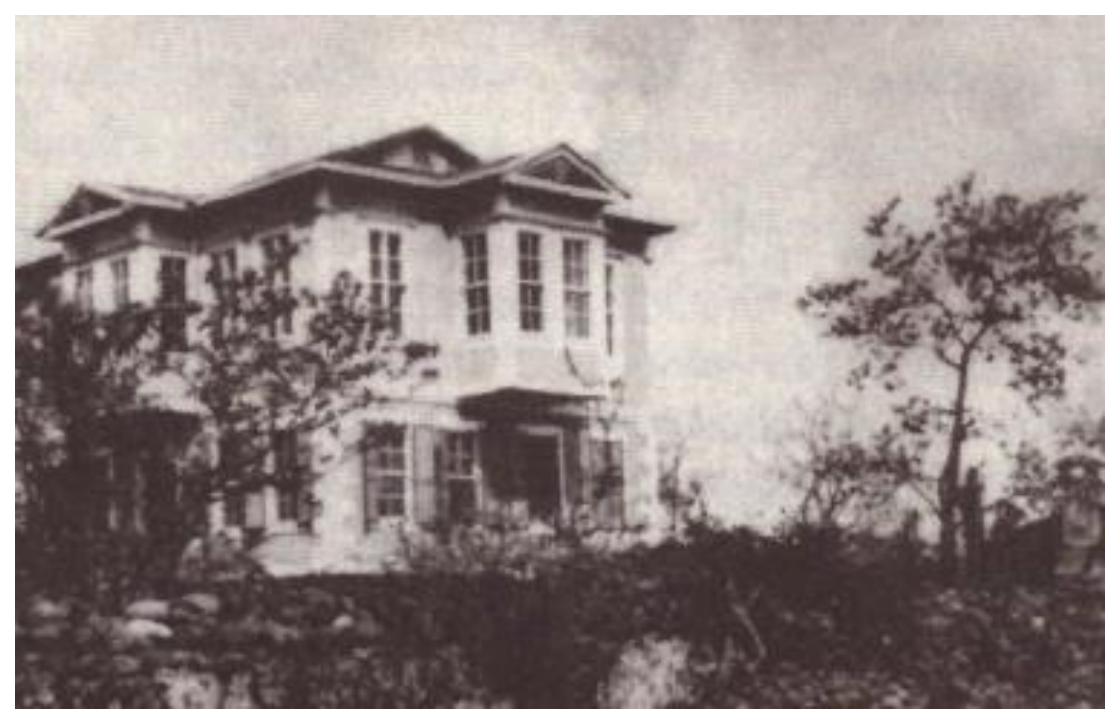

Görsel 34: Osman Bey Konağı (Emecen, 2020: 215)

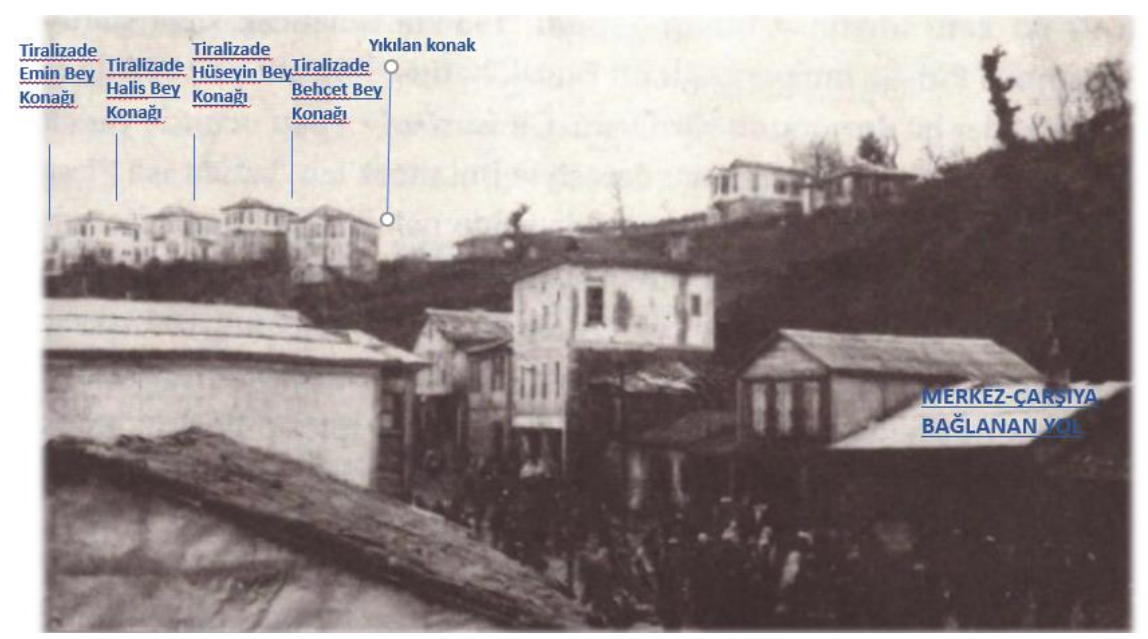

Görsel 35: Tiralizade Konaklarının Tümünü Gösteren Bir Fotoğraf (Emecen, 2020: 215) 